\title{
Coupling carbon allocation with leaf and root phenology predicts tree-grass partitioning along a savanna rainfall gradient
}

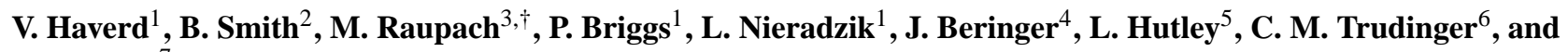 \\ J. Cleverly ${ }^{7}$ \\ ${ }^{1}$ CSIRO Oceans and Atmosphere, PO Box 3023, Canberra, ACT 2601, Australia \\ ${ }^{2}$ Lund University, Department of Physical Geography and Ecosystem Science, 22362 Lund, Sweden \\ ${ }^{3}$ Australian National University, Climate Change Institute, Canberra, ACT 0200, Australia \\ ${ }^{4}$ School of Earth and Environment, The University of Western Australia, M004, 35 Stirling Highway, \\ Crawley, WA 6009, Australia \\ ${ }^{5}$ Research Institute for the Environment and Livelihoods, Charles Darwin University, NT 0909, Australia \\ ${ }^{6}$ CSIRO Oceans and Atmosphere, PMB 1 Aspendale, VIC 3195, Australia \\ ${ }^{7}$ School of Life Sciences, University of Technology, Sydney, PO Box 123, Broadway, NSW 2007, Australia \\ $\dagger$ deceased
}

Correspondence to: V. Haverd (vanessa.haverd@csiro.au)

Received: 24 August 2015 - Published in Biogeosciences Discuss.: 5 October 2015

Revised: 27 December 2015 - Accepted: 6 January 2016 - Published: 11 February 2016

\begin{abstract}
The relative complexity of the mechanisms underlying savanna ecosystem dynamics, in comparison to other biomes such as temperate and tropical forests, challenges the representation of such dynamics in ecosystem and Earth system models. A realistic representation of processes governing carbon allocation and phenology for the two defining elements of savanna vegetation (namely trees and grasses) may be a key to understanding variations in tree-grass partitioning in time and space across the savanna biome worldwide. Here we present a new approach for modelling coupled phenology and carbon allocation, applied to competing tree and grass plant functional types. The approach accounts for a temporal shift between assimilation and growth, mediated by a labile carbohydrate store. This is combined with a method to maximize long-term net primary production (NPP) by optimally partitioning plant growth between fine roots and (leaves + stem). The computational efficiency of the analytic method used here allows it to be uniquely and readily applied at regional scale, as required, for example, within the framework of a global biogeochemical model.

We demonstrate the approach by encoding it in a new simple carbon-water cycle model that we call HAVANA (Hydrology and Vegetation-dynamics Algorithm for Northern Australia), coupled to the existing POP (Population Orders
\end{abstract}

Physiology) model for tree demography and disturbancemediated heterogeneity. HAVANA-POP is calibrated using monthly remotely sensed fraction of absorbed photosynthetically active radiation (fPAR) and eddy-covariance-based estimates of carbon and water fluxes at five tower sites along the North Australian Tropical Transect (NATT), which is characterized by large gradients in rainfall and wildfire disturbance. The calibrated model replicates observed gradients of fPAR, tree leaf area index, basal area, and foliage projective cover along the NATT. The model behaviour emerges from complex feedbacks between the plant physiology and vegetation dynamics, mediated by shifting above- versus below-ground resources, and not from imposed hypotheses about the controls on tree-grass co-existence. Results support the hypothesis that resource limitation is a stronger determinant of tree cover than disturbance in Australian savannas.

\section{Introduction}

Savannas constitute one of the world's most extensive biomes and provide ecosystem services as rangelands and marginal agricultural lands for one-fifth of the world's population (Lehmann et al., 2009). Being sensitive to variations 
in rainfall and water availability, they have a primary role in governing interannual variability in biosphere-atmosphere carbon exchange and the $\mathrm{CO}_{2}$ concentration of the atmosphere (Ahlström et al., 2015; Poulter et al., 2014). For the last three decades, semi-arid ecosystems (including savannas) globally have exhibited a positive net carbon uptake trend (Ahlström et al., 2015), coinciding with regional observations of woody encroachment and increased vegetation greenness when viewed from space (Donohue et al., 2009; Liu et al., 2015). The biogeochemical dynamics of seasonally dry savannas are modulated by stress tolerance and pulse response behaviour of the drought-adapted biota as the environment shifts seasonally in the relative availability of above(light) and below-ground (mainly water) resources. Resource competition - or avoidance of competition through spatial and temporal niche segregation (Ward et al., 2013) - between trees and grasses, as well as disturbances due to grazing animals and fires (Lehmann et al., 2014; Sankaran et al., 2005), drives shifts in allocation and tree versus grass performance that feed back to and tightly couple the water and carbon cycles. The relative complexity of the mechanisms underlying savanna ecosystem dynamics, in comparison to other biomes such as temperate and tropical forests, challenges the representation of such dynamics in ecosystem and Earth system models (Baudena et al., 2015).

Phenology and allocation of carbon to leaves, roots, and stems are critical determinants of savanna productivity (Ma et al., 2013; Scholes and Walker, 2004). Savanna vegetation occurs in regions of high rainfall variability and, while vegetation is often water-limited, light can limit production seasonally or during heavy precipitation episodes (Whitley et al., 2011). Species may partition available carbon seasonally and interannually in order to optimize uptake of variably available resources above and below ground. Resource availability often changes quickly: species respond by producing resource uptake surfaces quickly to optimize uptake of the most limiting resource - leaves to capture light when soil water is abundant, and fine roots to increase water uptake as supplies deplete. To enable a rapid response to changing resources, plants draw on stored non-structural carbohydrates (NSCs), which are accumulated during times of plenty. This must lead to a temporal shift between plant growth and carbon capture.

A realistic representation of processes governing carbon allocation and phenology for the defining elements of savanna vegetation (namely trees and grasses) may thus be a key to understanding variations in tree-grass partitioning in time and space in the savanna biome worldwide. Global vegetation models typically treat allocation and phenology as independent processes. One exception is the adaptive dynamic global vegetation model of Scheiter and Higgins (2009), which is specialized for the simulation of savannas. It uses an individual plant's carbon status to determine the transition between active and dormant states, dynamically allocating carbon based on resource (light or water) limitation. How- ever, no large-scale vegetation model of which we are aware allows phenology to emerge as a result of allocation of assimilated carbon to leaves and roots in response to changing relative availability of above- and below-ground resources during the course of a growing season or between years.

Here we present a new approach that links phenology and allocation, accounting for a temporal shift between assimilation and growth, which is mediated by a labile carbohydrate store. The novelty of the approach lies in the dynamic constraint of plant growth such that the long-term change in store (net primary production minus growth) is zero (a requirement for carbon conservation). This is combined with the use of an optimal response method for analytically predicting the partitioning of plant growth between fine roots and (leaves + stem), which optimizes long-term NPP. While optimal response methods for carbon allocation are not new (Franklin et al., 2012) and have been applied to savanna vegetation (Schymanski et al., 2009), the computational efficiency of the analytic method used here allows it to be uniquely readily applied at regional scale, as required, for example, within the framework of a land surface model (LSM) or Earth system model.

We demonstrate the approach by encoding it in a simple carbon/water cycle model that we call HAVANA (Hydrology and Vegetation-dynamics Algorithm for Northern Australia), coupled to the POP (Population Orders Physiology) model for tree demography and disturbance-mediated heterogeneity (Haverd et al., 2013b, 2014). HAVANA-POP is applied to and tested against observations from the North Australian Tropical Transect (NATT), featuring gradients in rainfall and wildfire disturbance. In particular, the model is evaluated against a suite of observations that are sensitive to the treegrass ratio along the transect, namely eddy-covariance-based estimates of carbon and water fluxes at five tower sites, dynamics of remotely sensed fPAR, tree leaf area index derived from digital hemispheric photography and satellite observations, and gradients of tree basal area and foliage projective cover.

\section{Model description}

HAVANA is a new model of landscape water balance and plant function. It contains two water stores (upper and lower soil) and leaf and fine root compartments for each of two competing vegetation types: trees and grass. The tree vegetation type also has a stem compartment, which includes coarse roots. The stem compartment is partitioned between sapwood and heartwood via coupling to the POP module (Haverd et al., 2013b), which accounts for tree demography and landscape heterogeneity mediated by disturbance.

Qualitative relationships between key variables for a single vegetation type (trees) are shown in Fig. 1. The schematic also applies to grass, except that the stem component does not apply in grasses, and grass fine roots do not access the 


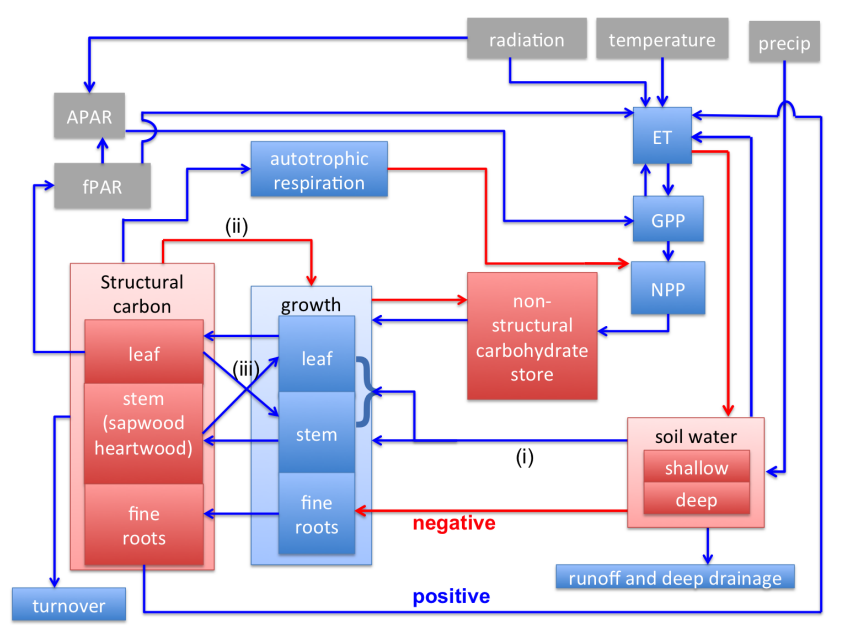

Figure 1. Schematic showing the key elements of HAVANA, and the qualitative relationships between them. Carbon and water pools are represented by red boxes and fluxes by blue boxes. Blue (red) arrows show positive (negative) feedbacks. Less intuitive feedbacks are as follows. (i) Soil water influence on growth: soil water positively impacts on total growth, while there is a negative feedback of soil moisture on allocation to fine roots, in favour of the combined (leaf + stem) compartment; (ii) growth responds negatively to the structural carbon store as it approaches carbon carrying capacity Eq (1.0); and (iii) partitioning of growth between leaf and stem is influenced by the relative magnitudes of leaf and sapwood compartments, which are constrained by the pipe model (Shinozaki et al., 1964), in which sapwood cross-sectional area is assumed to be a constant proportion of total leaf area.

deep soil moisture store. Although not represented in Fig. 1, trees and grass interact via competition for water in the shallow upper soil layer and competition for light.

In the model, soil water stores change in response to input from precipitation and losses due to evapotranspiration, deep drainage and surface runoff (Fig. 1). Dynamics of vegetation carbon stores are governed by growth and turnover rates. Growth is constrained to be equal to net primary production (NPP, equal to gross primary production minus autotrophic respiration) in the long term, but is temporally dependent on the size of an implicit NSC store, soil water availability and the deviation of the structural carbon store from an internally computed carbon carrying capacity, above which growth stops and NPP is stored away as NSCs. No assumption is made as to the absolute size of the NSC store; rather, it is the cumulative deviation due to the imbalance between NPP and growth that is maintained as a state variable of the model. Growth is partitioned between (leaf + stem) and fine root compartments using an optimal response theory in which long-term NPP is the fitness proxy. That is, we assume the ecological optimality hypothesis, that evolutionary selection pressures drive ecosystems towards maximal utilization of available resources for the production of biomass, so that long-term NPP over many reproductive cycles takes the largest possible value under the constraints of available resources (Raupach, 2005). This leads to a negative feedback of soil moisture on allocation to fine roots, in favour of the combined (leaf + stem) compartment. Partitioning of growth between leaf and stem is influenced by the relative magnitudes of leaf and sapwood compartments, which are constrained by the pipe model (Shinozaki et al., 1964), in which sapwood cross-sectional area is assumed to be a constant proportion of total leaf area. Leaf and fine root carbon stores are subject to first-order decay, while turnover of woody biomass is given by the mortality (both resource-limitation and disturbance components, including fire) computed within the POP module (Sect. 2.3 and Appendix A).

The carbon and water cycles are primarily linked by the transpiration component of evapotranspiration, with a secondary link being the dependences of growth and growth partitioning on soil moisture. Transpiration, equivalent to root water extraction, is modelled as the lesser of evaporative demand (dependent on radiation, air temperature, and fraction cover) and supply-limited root water uptake, which depends both on soil moisture and root density in each soil layer.

Trees and grass compete for light and water. Tree roots can potentially access water in both shallow and deep soil layers, whereas grass roots are assumed unable to access the deep soil moisture store. Further, grass is partially shaded by trees as a function of tree cover.

A quantitative description of the model follows. All parameter symbols, meanings, values, and sources are listed in Table 1 . The time step is 1 day.

\subsection{Water balance model}

The water balance model is that of the Australian Water Availability Project (Raupach et al., 2009), with modification to the transpiration terms to allow for root carbon dependence, and is described here in full for completeness.

\section{State variables}

The two state variables of the water balance model are soil water stores $\left(W_{1}, W_{2}\right)$ [m water] corresponding to upper and lower soil layers, the boundary between them corresponding to the approximate vertical extent of the grass root profile (Janos et al., 2008), and the total depth of the tree roots (Hutley et al., 2000). The layers together encompass the whole soil profile from which water is extracted by plant transpiration. Corresponding dimensionless variables are the relative soil water $\left(w_{1}, w_{2}\right)$ in the two stores, between 0 and 1 and related to $W_{1}$ and $W_{2}$ by

$w_{i}=W_{i} /\left(\theta_{S_{i}} Z_{W_{i}}\right) \quad(i=1,2)$,

where $\theta_{S i}\left[\mathrm{~m}^{3} \mathrm{~m}^{-3}\right]$ is the saturated volumetric water content and $Z_{W_{i}}[\mathrm{~m}]$ is the thickness of layer $i$ (Table 1). 
Table 1. Model parameters.

\begin{tabular}{|c|c|c|c|c|c|}
\hline Parameter & Units & Value & Meaning & Equation & Source \\
\hline$\theta_{\mathrm{S} 1}$ & {$\left[\mathrm{~m}^{3} \mathrm{~m}^{-3}\right]$} & $\begin{array}{l}\text { Spatially } \\
\text { variable }\end{array}$ & $\begin{array}{l}\text { Saturated volumetric water } \\
\text { content (upper soil layer) }\end{array}$ & (1) & Sect. 3.1 \\
\hline$\theta_{\mathrm{S} 2}$ & {$\left[\mathrm{~m}^{3} \mathrm{~m}^{-3}\right]$} & $\begin{array}{l}\text { Spatially } \\
\text { variable }\end{array}$ & $\begin{array}{l}\text { Saturated volumetric water } \\
\text { content (lower soil layer) }\end{array}$ & (1) & Sect. 3.1 \\
\hline$Z_{\mathrm{W} 1}$ & {$[\mathrm{~m}]$} & 0.2 & Depth of upper soil layer & (1) & Janos et al. (2008) \\
\hline$Z_{\mathrm{W} 2}$ & {$[\mathrm{~m}]$} & 4.0 & Depth of lower soil layer & (1) & Hutley et al. (2000) \\
\hline$c_{\mathrm{PT}}$ & [ ] & 1.26 & Priestley-Taylor coefficient & (1) & Priestley and Taylor (1972) \\
\hline$G_{\mathrm{a}}$ & {$\left[\mathrm{m} \mathrm{s}^{-1}\right]$} & 0.015 & Aerodynamic Conductance & (1) & This work (fixed) \\
\hline$p_{\text {extract }}$ & [ ] & 0.421 & Exponent in root water extraction & (1) & This work (calibrated) \\
\hline$k_{\mathrm{E}, \mathrm{g}}$ & {$\left[\mathrm{m} \mathrm{d}^{-1}\left(\mathrm{molCm}^{-2}\right)^{-1}\right]$} & $6.14 \times 10^{-4}$ & $\begin{array}{l}\text { Rate constant for root } \\
\text { water extraction (grass) }\end{array}$ & (1) & This work (calibrated) \\
\hline$k_{\mathrm{E}, \mathrm{w}}$ & {$\left[\mathrm{m} \mathrm{d}^{-1}\left(\mathrm{molC} \mathrm{m}^{-2}\right)^{-1}\right]$} & $6.12 \times 10^{-4}$ & Rate constant for root water extraction (trees) & (1) & This work (calibrated) \\
\hline$\beta$ & [ ] & 8.88 & $\begin{array}{l}\text { Exponent specifying the response of soil } \\
\text { evaporation to upper-layer soil water }\end{array}$ & $(1)$ & This work (calibrated) \\
\hline$g$ & [ ] & 1.30 & $\begin{array}{l}\text { Exponent specifying the response } \\
\text { of drainage to relative soil water }\end{array}$ & (1) & This work (calibrated) \\
\hline$K_{\mathrm{S} 1}$ & {$\left[\mathrm{~m} \mathrm{~d}^{-1}\right]$} & Spatially variable & $\begin{array}{l}\text { Saturated hydraulic conductivity } \\
\text { of soil layer } 1\end{array}$ & (1) & See Sect. 3.1 \\
\hline$K_{\mathrm{S} 2}$ & {$\left[\mathrm{~m} \mathrm{~d}^{-1}\right]$} & Spatially variable & $\begin{array}{l}\text { Saturated hydraulic conductivity } \\
\text { of soil layer } 2\end{array}$ & (1) & See Sect. 3.1 \\
\hline$k_{\mathrm{L}, \mathrm{g}}$ & {$\left[\mathrm{d}^{-1}\right]$} & $1 / 67$ & $\begin{array}{l}\text { First-order rate constant } \\
\text { for leaf turnover (grass) }\end{array}$ & (1) & This work (calibrated) \\
\hline$k_{\mathrm{R}, \mathrm{g}}$ & {$\left[\mathrm{d}^{-1}\right]$} & $k_{\mathrm{L}, \mathrm{g}}$ & $\begin{array}{l}\text { First-order rate constant } \\
\text { for fine root turnover (grass) }\end{array}$ & (1) & Janos et al. (2008) \\
\hline$k_{\mathrm{R}, \mathrm{w}}$ & {$\left[\mathrm{d}^{-1}\right]$} & $1 / 256$ & $\begin{array}{l}\text { First-order rate constant } \\
\text { for fine root turnover (trees) }\end{array}$ & (1) & Vogt et al. (1995) \\
\hline$b_{\text {growth }}$ & [ ] & 6.17 & growth scaling parameter & (1) & This work (calibrated) \\
\hline$F_{0, \text { growth }}$ & {$\left[\mathrm{mol} \mathrm{C} \mathrm{m}{ }^{-2} \mathrm{~d}^{-1}\right]$} & 0.017 & $\begin{array}{l}\text { Residual growth flux to allow for } \\
\text { regeneration from seed or resprouting }\end{array}$ & (1) & This work (calibrated) \\
\hline$k_{\text {store }}$ & [ ] & 10.0 & $\begin{array}{l}\text { Parameter controlling contribution } \\
\text { of flux to NSC store to growth rate }\end{array}$ & (1) & This work (fixed) \\
\hline$p_{\text {growth }}$ & [ ] & 3.0 & $\begin{array}{l}\text { Parameter controlling steepness of soil } \\
\text { moisture function used in growth formulation }\end{array}$ & (1) & This work (fixed) \\
\hline$w_{\text {thresh }}$ & [ ] & 0.362 & $\begin{array}{l}\text { Relative soil moisture threshold in soil } \\
\text { moisture function used in growth formulation }\end{array}$ & (1) & This work (calibrated) \\
\hline$K_{\text {growth }}$ & [ ] & 0.02 & $\begin{array}{l}\text { Scaling parameter controlling rate of } \\
\text { change of the dynamic carrying capacity. }\end{array}$ & (1) & This work (fixed) \\
\hline $\mathrm{C}_{0}$ & {$\left[\mathrm{~mol} \mathrm{C} \mathrm{m}^{-2}\right]$} & 0.001 & Minimum carrying capacity & (1) & This work (fixed) \\
\hline$c_{\text {growth }}$ & [ ] & 0.2 & Growth respiration coefficient & (1) & Ryan (1991) \\
\hline$\alpha_{\mathrm{Q}}$ & {$\left[\mathrm{molC} \mathrm{mol} \mathrm{quanta}^{-1}\right]$} & 0.0198 & PAR use efficiency (trees and grass) & (1) & This work (calibrated) \\
\hline$m_{\alpha, \mathrm{g}}$ & [ ] & $1.5 m_{\alpha, \mathrm{w}}$ & $\begin{array}{l}\text { Dimensionless multiplier in } \\
\text { equation for water use efficiency, grass }\end{array}$ & (1) & Singh and Misra (1985) \\
\hline$m_{\alpha, \mathrm{w}}$ & [ ] & 0.493 & $\begin{array}{l}\text { Dimensionless multiplier in } \\
\text { equation for water use efficiency, trees }\end{array}$ & (1) & This work (calibrated) \\
\hline$k_{\text {resp }}$ & {$\left[\mathrm{d}^{-1}\right]$} & 0.0548 & Rate constant for maintenance respiration & (1) & Sprugel et al. (1995) \\
\hline${ }^{\text {ratio }} \mathrm{CtoN}$,sapwood & {$\left[\mathrm{gC}(\mathrm{gN})^{-1}\right]$} & 300 & Carbon to nitrogen mass ratio in sapwood & (1) & Sitch et al. (2003) \\
\hline ratio $_{\text {CtoN, leaf }}$ & {$\left[\mathrm{gC}(\mathrm{gN})^{-1}\right]$} & 30 & Carbon to nitrogen mass ratio in leaves & (1) & Sitch et al. (2003) \\
\hline ratio $\mathrm{CtoN}$,roots & {$\left[\mathrm{gC}(\mathrm{gN})^{-1}\right]$} & 30 & Carbon to nitrogen mass ratio in fine roots & (1) & Sitch et al. (2003) \\
\hline$k_{\mathrm{LA}}: \mathrm{SA}$ & [ ] & 3000 & $\begin{array}{l}\text { Ratio of leaf area to } \\
\text { sapwood cross-sectional area }\end{array}$ & (1) & McDowell et al. (2002) \\
\hline$c_{\text {Ext }}$ & [ ] & 0.6 & Extinction coefficient for PAR & (1) & This work (fixed) \\
\hline$A_{\mathrm{SL}, \mathrm{g}}$ & {$\left[\mathrm{cm}^{2} \mathrm{~g}(\mathrm{DW})^{-1}\right]$} & 120.0 & $\begin{array}{l}\text { Specific leaf area, grass } \\
\text { (L. Hutley, personal communication, 2015) } \\
\text { to account for clumping }\end{array}$ & (1) & $\begin{array}{l}\text { Lower than the recommended } \\
\text { values of } 175\end{array}$ \\
\hline
\end{tabular}




\section{Balance equations}

The dynamic equations governing $W_{1}$ and $W_{2}$ are the mass conservation equations for soil water:

$$
\begin{aligned}
& \frac{\mathrm{d} W_{1}}{\mathrm{~d} t}=\theta_{S_{1}} Z_{W_{1}} \frac{\mathrm{d} w_{1}}{\mathrm{~d} t}=\underset{\text { Precipitation }}{F_{\text {WPrec }}}-
\end{aligned}
$$

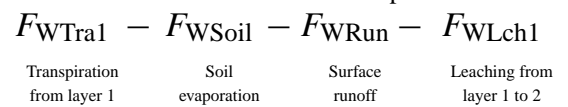

$$
\begin{aligned}
& \frac{\mathrm{d} W_{2}}{\mathrm{~d} t}=\theta_{S_{2}} Z_{W_{2}} \frac{\mathrm{d} w_{2}}{\mathrm{~d} t}=F_{\substack{\text { Leaching from } \\
\text { layer 1 to } 2}} \\
& F_{\mathrm{WLch} 2}-F_{\mathrm{WTra} 2}, \\
& \begin{array}{cc}
\text { Deep } & \text { Transpiration } \\
\text { drainage } & \text { from layer 2 }
\end{array}
\end{aligned}
$$

where all water fluxes $\left(F_{\mathrm{W}}\right)$ are in metres of water per day $\left[\mathrm{m} \mathrm{H}_{2} \mathrm{Od}^{-1}\right]$.

\section{Phenomenological equations}

The phenomenological equations for water fluxes are as follows.

(1) Precipitation $\left(F_{\mathrm{WPrec}}\right)$ is an external input. (2) Transpiration $\left(F_{\mathrm{WTra}}\right)$ is defined for each soil layer $(i=1,2)$ and each plant type $(j=\operatorname{grass}[g]$, trees $[\operatorname{wood}=w])$ as the lesser of an energy-limited transpiration rate $F_{\mathrm{WTr} \text { (ELim), } j}$ and a water-limited transpiration rate $F_{\mathrm{WTra}(\mathrm{WLim}), j}$ :

$F_{\mathrm{WTra}, i, j}=\min \left(F_{\mathrm{WTra}(\mathrm{ELim}) i, j}, \quad F_{\mathrm{WTra}(\mathrm{WLim}) i, j}\right)$.

(Note here that $F_{\mathrm{WTra}, 2 \text {,grass }}=0$, as it is assumed that grass roots do not access the lower soil moisture store.)

The total energy-limited transpiration rate (summed over two soil layers) is partitioned among soil layers using the water-limited transpiration for each layer under prevailing (energy-limited) conditions, so that

$F_{\mathrm{WTra}(\mathrm{Elim}) i, j}=F_{\mathrm{WTra}(\mathrm{Elim}) j}$

$\left[F_{\mathrm{WTra}(\mathrm{Wlim}) i, j} /\left(F_{\mathrm{WTra}(\mathrm{Wlim}) 1, j}+F_{\mathrm{WTra}(\mathrm{Wlim}) 2, j}\right)\right]$.

The total energy-limited transpiration rate, $F_{\mathrm{WTra}(\mathrm{ELim}) \text {, and }}$ the water-limited transpiration for each layer, $F_{\mathrm{WTra}(\mathrm{WLim}) i}$, are defined as follows.

The total energy-limited transpiration rate is the evaporation rate from the surface without soil water constraints. It is often defined using the Penman-Monteith equation, but for reasons of both physics (Raupach, 2000, 2001) and simplicity, it is defined here as

$F_{\mathrm{WTra}(\mathrm{ELim}), j}=v_{j} F_{\mathrm{W}(\mathrm{PT})}$,

where $v_{j}$ is the tree or grass vegetation cover fraction and $F_{\mathrm{W}(\mathrm{PT})}$ is the Priestley-Taylor evaporation rate $\left[\mathrm{m} \mathrm{H}_{2} \mathrm{O} \mathrm{d}^{-1}\right]$, a thermodynamic estimate of the energy-limited evaporation rate for the whole surface (vegetation plus soil). The factor $v_{j}$ relates energy-limited total evaporation to the plant component only.

From Raupach $(2000,2001), F_{\mathrm{W}(\mathrm{PT})}$ is

$F_{\mathrm{W}(\mathrm{PT})}=c_{\mathrm{PT}} \Phi_{\mathrm{Eq}} /\left(\rho_{\mathrm{W}} \lambda \mathrm{W}\right)$,

where $\rho_{\mathrm{W}}\left[\mathrm{mol} \mathrm{H}_{2} \mathrm{O} \mathrm{m}^{-3}\right]$ is the density of liquid water, $\lambda_{\mathrm{W}}$ [ $\mathrm{J} \mathrm{mol} \mathrm{H}_{2} \mathrm{O}^{-1}$ ] is the latent heat of vaporization of water, $\Phi_{E q}\left[\mathrm{~J} \mathrm{~m}^{-2} \mathrm{~d}^{-1}\right]$ is the thermodynamic equilibrium latent heat flux, and $c_{P T}$ is the Priestley-Taylor coefficient, a number which is well constrained at about 1.26 (Priestley and Taylor, 1972; Raupach, 2001). The equilibrium latent heat flux is given by

$\Phi_{\mathrm{Eq}}=p \varepsilon \Phi_{\mathrm{A}}^{*} /(p \varepsilon+1)$,

where $\Phi_{\mathrm{A}}^{*}$ is the isothermal available energy flux, $\varepsilon$ is the ratio of latent to sensible heat content of saturated air $(2.2$ at $20^{\circ} \mathrm{C}$, roughly doubling with each $13{ }^{\circ} \mathrm{C}$ temperature increase), and $p$ is a number slightly less than 1 accounting for radiative coupling:

$p=\frac{G_{\mathrm{a}}}{G_{\mathrm{a}}+G_{\mathrm{r}}}$,

where $G_{\mathrm{a}}$ is the aerodynamic conductance for heat and water vapour transfer, $G_{\mathrm{r}}=4 e \sigma T_{a}^{3} /\left(\rho_{\mathrm{A}} c_{\mathrm{PA}}\right)$ is the radiative conductance, $\rho_{\mathrm{A}}\left[\mathrm{mol} \mathrm{m}^{-3}\right]$ is the density of air, and $c_{P A}$ is the specific heat of air at constant pressure $\left[\mathrm{J} \mathrm{mol}^{-1} \mathrm{~K}^{-1}\right]$.

The isothermal available energy flux $\Phi_{\mathrm{A}}^{*}$ is given by

$\Phi_{\mathrm{A}}^{*}=(1-a) \Phi_{\mathrm{S} \downarrow}+e\left(\Phi_{\mathrm{L} \downarrow}-\sigma T_{\mathrm{a}}^{4}\right)$,

where $\Phi_{\mathrm{S}_{\downarrow}}$ and $\Phi_{\mathrm{L}_{\downarrow}}$ are the downward solar (shortwave) and thermal (longwave) irradiances; $a$ and $e$ are wholesurface albedo and emissivity, respectively; $\sigma$ is the StefanBoltzmann constant; and $T_{\mathrm{a}}[\mathrm{K}]$ is the air temperature at a reference height.

Energy fluxes $(\Phi)$ are calculated as averages over daylight hours only, since it is assumed that total evaporation $\left(F_{\mathrm{WE}}=F_{\mathrm{WTra}}+F_{\mathrm{WSoil}}\right)$ and its components are all zero at night. Downward daytime longwave irradiance is estimated with the Swinbank (1963) formula

$\Phi_{\mathrm{L} \downarrow}=335.97\left(T_{\mathrm{a}} / 293\right)^{6.0}$,

using average daytime $T_{\mathrm{a}}$ estimated as $0.75 T_{\mathrm{a}, \max }+$ $0.25 T_{\mathrm{a}, \min }$.

The water-limited transpiration rate in layer $i$ by plant type $j$ is parameterized as

$F_{\mathrm{WTra}(\mathrm{WLim}) i, j}=k_{\mathrm{E}, i, j} C_{\mathrm{R}, i, j} w_{i}^{p_{\mathrm{extract}}}$,

where $k_{\mathrm{E} i, j}$ is a rate per unit root carbon density $\left[\mathrm{m} \mathrm{d}^{-1}\right.$ $\left(\mathrm{mol} \mathrm{C} \mathrm{m}{ }^{-2}\right)^{-1}$ ] for the uptake of water by roots from a drying soil under water-limited transpiration, and $C_{\mathrm{R}, i, j}$ is the root carbon density $\left[\mathrm{mol} \mathrm{C} \mathrm{m}^{-2}\right.$ ] of soil layer $i$ and plant type $j$. 
(3) Soil evaporation $\left(F_{\mathrm{WSoil}}\right)$ is formulated as

$F_{\mathrm{WSoil}}=(1-v) w_{1}^{\beta} F_{\mathrm{W}(\mathrm{PT})}$,

where $\beta$ is an exponent specifying the response of soil evaporation to upper-layer soil water $\left(w_{1}\right)$.

(4) Surface runoff $\left(F_{\mathrm{WRun}}\right)$ is given by

$F_{\mathrm{WRun}}=F_{\mathrm{WPrec}} \operatorname{Step}\left(w_{1}-1\right)$.

All precipitation runs off when the upper-layer soil is saturated, and there is no runoff otherwise.

(5) Leaching $\left(F_{\mathrm{WLch}}\right)$ or drainage downward out of soil layer $i$ is given by

$F_{\mathrm{WLch}, i}=K_{\mathrm{S}, i} w_{i}^{\gamma}$,

where $\gamma$ is an exponent specifying the response of drainage to relative soil water $w_{i}$, and $K_{\mathrm{S}, i}\left[\mathrm{~m} \mathrm{~d}^{-1}\right]$ is the saturated hydraulic conductivity of soil layer $i$.

\subsection{Model of vegetation function}

\section{State variables and governing equations}

The state variables of the vegetation model are carbon pools in leaves and fine roots of trees and grass, and the woody carbon pool (stem plus coarse roots) in trees, and the cumulative difference between NPP and growth, which equates to the deviations of NSCs for trees and grasses from an (unknown) baseline value. A single set of parameters was adopted for all trees and all grasses individually. Common parameter sets were adopted for all trees and all grasses respectively: species were not distinguished. The dynamics of these pools are governed by their mass conservation equations, with each pool augmented by a proportion $\alpha$ of the growth flux. Leaf and fine root pools are depleted by first-order decay, while all tree carbon pools are depleted by tree mortality:

$$
\begin{aligned}
& \frac{\mathrm{d} C_{\mathrm{L}, j}}{\mathrm{~d} t}=\alpha_{\mathrm{L}, j} F_{\mathrm{C}, \text { growth }, j}-k_{\mathrm{L}, j} C_{\mathrm{L}, j} \\
& -\frac{C_{\mathrm{L}, j}}{C_{\mathrm{stem}}} m_{\mathrm{stem}, j}, \\
& \frac{\mathrm{d} C_{\mathrm{R}, i, j}}{\mathrm{~d} t}=\alpha_{\mathrm{R}, i, j} F_{\mathrm{C}, \text { growth }, j}-k_{\mathrm{R}, j} C_{\mathrm{R}, i, j} \\
& -\frac{C_{\mathrm{R}, i, j}}{C_{\text {stem }}} m_{\mathrm{stem}, j}, \\
& \frac{\mathrm{d} C_{\text {stem }}}{\mathrm{d} t}=\alpha_{\mathrm{stem}} F_{\mathrm{C}, \text { growth }, \mathrm{w}}-m_{\mathrm{stem}} .
\end{aligned}
$$

In Eqs. (15) to (17), $C$ denotes a carbon pool $\left[\mathrm{mol} \mathrm{C} \mathrm{m}^{-2}\right]$; $\alpha$ a carbon allocation coefficient; $L$ is leaves; $R$ is fine roots; "stem" is trunk plus coarse roots; $k$ is a first-order rate constant $\left[\mathrm{d}^{-1}\right] ; j$ is a plant type (woody or grassy) and $i$ a soil layer (upper or lower); and $m_{\text {stem, } j}$ is stem biomass turnover $\left[\mathrm{mol} \mathrm{C} \mathrm{m}{ }^{-2} \mathrm{~d}^{-1}\right]$, which is zero for grass, and computed by POP for trees (see Sect. 2.3).
For woody vegetation, we adopt a dependence of leaf turnover on specific leaf area, based on the synthesis of Wright et al. (2002):

$k_{\mathrm{L}, \mathrm{w}}=1 /\left(365\left(\frac{A_{\mathrm{SL}, \mathrm{w}}}{60}\right)^{-1.2}\right)$.

\section{Growth}

Growth (the flux of carbon to structural components) is parameterized by a logistic curve, inspired by Choler et al. (2010), who specified growth of grasses in watercontrolled ecosystems as the product of (i) a growth scaling parameter; (ii) relative soil moisture content; (iii) 1 minus current leaf carbon, relative to a fixed carrying capacity; and (iv) current leaf carbon. In contrast we specify growth following Eq. (1) as the product of (i) a growth scaling parameter $\left(\beta_{\text {growth }}\right)$; (ii) $f_{\mathrm{w}, j}$, an increasing function of soil water in the upper soil layer (grass) or lower soil layer (trees, Eq. 1) (NB: trees and grass nonetheless compete for water in the upper soil layer via transpiration); (iii) 1 minus (leaf + fine root) carbon relative to a prognostic carrying capacity $C_{\max , j}$, above which growth stops and net primary production is stored away as non-structural carbohydrate; and (iv) the sum of (a) long-term NPP, (b) a multiple of the long-term net flux (NPP - growth) to the NSC store, and (c) a residual

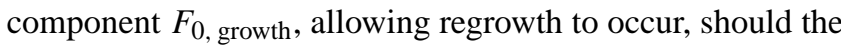
plant $C$ stores decline to zero.

$$
\begin{aligned}
& F_{\mathrm{C}, \text { growth }, j}=\beta_{\text {growth }} f_{\mathrm{w}, j} \\
& \max \left[\left(1-\frac{C_{\text {leaf }, j}+\sum_{i} C_{\mathrm{R}, i, j}}{C_{\mathrm{max}, j}}\right), 0.0\right] \\
& \left.\left.+k_{\text {store }}\left(\overline{F_{\mathrm{C}, \mathrm{NPP}, j}}-\overline{F_{\mathrm{C}, \text { growth }, j}}\right), 0.0\right]\right) . \\
& f_{w}=\frac{1-\left(1+\left(\frac{\mathrm{w}}{\mathrm{w}_{\text {thresh }}}\right)^{p_{\text {growth }}}\right)^{-1}}{1-\left(1+\left(\frac{1}{\mathrm{w}_{\text {thresh }}}\right)^{p_{\text {growth }}}\right)^{-1}} .
\end{aligned}
$$

\section{Dynamic storage (coupling of net primary production and growth)}

Growth is constrained to equal time-averaged NPP over some averaging period $\left(t_{\mathrm{av}, j}\right.$; set here to 1 year for grass and 3 years for trees), producing a change in storage of carbohydrate (NPP minus growth) which averages to zero. This is 
achieved by adjusting $C_{\max , j}$ dynamically according to

$$
\begin{aligned}
& \frac{\mathrm{d} C_{\max , j}}{\mathrm{~d} t}=
\end{aligned}
$$

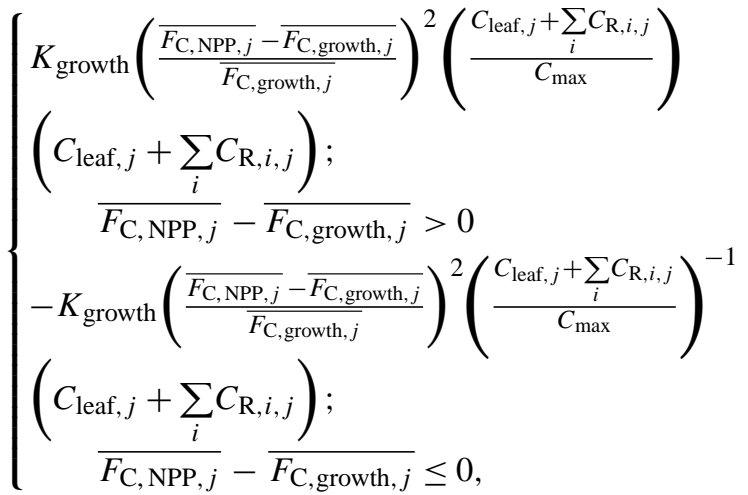

such that $C_{\max , j}$ increases if time-averaged net primary production exceeds growth and decreases otherwise. $C_{\max , j}$ is maintained above $C_{0}$.

\section{Net primary production}

Net primary production is the difference between gross primary production $\left(F_{\mathrm{C}, \mathrm{GPP}, j}\right)$ and maintenance respiration of leaves and fine roots, scaled by $\left(1-c_{\text {growth }}\right)$ to account for growth respiration (Ryan, 1991):

$$
\begin{aligned}
& F_{\mathrm{C}, \mathrm{NPP}, j}=\left(1-c_{\text {growth }}\right) \\
& \left(F_{\mathrm{C}, \mathrm{GPP}, j}-\sum_{i} F_{\mathrm{C}, \mathrm{R} m, \mathrm{R}, i, j}-F_{\mathrm{C}, \mathrm{R} m, \mathrm{~L}, j}-F_{\mathrm{C}, \mathrm{R} m, w}\right) .
\end{aligned}
$$

\section{Gross primary production}

Plant gross primary production $\left(F_{\mathrm{C}, \mathrm{GPP}, j}\right)$ is evaluated as the lesser of light- and water-limited components:

$F_{\mathrm{C}, \mathrm{GPP}, j}=\min \left[\left(\alpha_{\mathrm{Q}, j} v_{j} F_{\mathrm{Q}}\right),\left(\alpha_{\mathrm{W}} \rho_{\mathrm{W}} F_{\mathrm{WTra}, j}\right)\right]$,

where $F_{\mathrm{Q}}$ is the incident quantum flux of photosynthetically active radiation (PAR) on the surface [mol quanta $\mathrm{m}^{-2} \mathrm{~d}^{-1}$ ], and $\alpha_{\mathrm{Q}}$ and $\alpha_{\mathrm{W}}$ are respectively a PAR use efficiency $\left[\mathrm{molC}\right.$ mol quanta $\left.{ }^{-1}\right]$ and a transpired-water use efficiency $\left[\mathrm{molC} \mathrm{mol} \mathrm{H}_{2} \mathrm{O}^{-1}\right.$ ]. Of these, $\alpha_{\mathrm{Q}}$ is a prescribed parameter, and $\alpha_{\mathrm{W}}$ is calculated as

$\alpha_{\mathrm{W}}=m_{\alpha, j}\left(\left[\mathrm{CO}_{2}\right]_{\mathrm{a}}-\left[\mathrm{CO}_{2}\right]_{\mathrm{c}}\right) /\left(1.6 D_{\mathrm{s}}\right)$,

where $m_{\alpha, j}$ is a dimensionless multiplier, $\left[\mathrm{CO}_{2}\right]_{\mathrm{a}}$ is the atmospheric $\mathrm{CO}_{2}$ concentration, $\left[\mathrm{CO}_{2}\right]_{\mathrm{c}}$ is the $\mathrm{CO}_{2}$ compensation point [molC molAir ${ }^{-1}$ ] calculated using the Von Caemmerer (2000) algorithm:

$\left[\mathrm{CO}_{2}\right]_{\mathrm{c}}=37.0 \times 10^{-6} \times 1.37^{\frac{T_{\mathrm{s}}-25.0}{10.0}}$.

$D_{\mathrm{S}}$ is the surface saturation deficit $\left[\mathrm{mol} \mathrm{H}_{2} \mathrm{O}^{-1}\right.$ molAir $\left.^{-1}\right]$, calculated from the air saturation deficit $D_{\mathrm{a}}$ as in Raupach
(1998),

$D_{\mathrm{s}}=D_{\mathrm{a}}+\frac{\varepsilon\left(p\left(\Phi_{\mathrm{A}}-\Phi_{E}\right)\right)-\Phi_{E}}{\rho_{\mathrm{A}} c_{p} G_{\mathrm{a}}}$,

and surface temperature, $T_{\mathrm{s}}$, is given by

$T_{\mathrm{S}}=T_{\mathrm{a}}+\frac{\varepsilon\left(p\left(\Phi_{\mathrm{A}}-\Phi_{E}\right)\right)}{\rho_{\mathrm{A}} c_{p} G_{\mathrm{a}}}$.

\subsection{Maintenance respiration}

The rate of maintenance respiration for the $j$ th compartment (sapwood, leaf or fine roots) is formulated as

$R_{m, j}=k_{\mathrm{resp}} C_{j} / \mathrm{ratio}_{\mathrm{CtoN}, j} g\left(T_{\mathrm{a}}\right)$,

where $k_{\text {resp }}=0.0548 \mathrm{~d}^{-1}$ is the rate constant for maintenance respiration (Sprugel et al., 1995), and $g(T)$ is the ecosystem respiration temperature response function of Lloyd and Taylor (1994) adopted by Sitch et al. (2003) in the LPJ (LundPotsdam-Jena) model,

$g(T)=\exp \left[308.56\left(\frac{1}{56.02}-\frac{1}{T-227.13}\right)\right]$,

and ratio ${ }_{\text {CtoN }}$ is the mass ratio of carbon to nitrogen in the plant tissue, here taken as 30 for leaves and fine roots, and 300 for sapwood.

\subsection{Carbon allocation}

The allocation scheme governs the partitioning of growth between leaf, root, and (for trees) stem compartments. Allocation of assimilated carbon to reproduction is not considered. Following Raupach (2005), we choose time-dependent carbon allocation coefficients to maximize the total carbon gain, namely the long-term integral of $F_{\mathrm{C}, \mathrm{NPP}, j}$ for each plant type. As discussed by Raupach (2005), the vector of allocation coefficients has "bang-bang" character, meaning that, at each instant $t$, an allocation coefficient of 1 is assigned to the pool for which the marginal return on invested growth is largest while all the other pools receive zero allocation:

$$
\begin{aligned}
& \alpha_{\mathrm{L}, j}+\alpha_{\mathrm{stem}, j}=H\left[\frac{\delta F_{\mathrm{C}, \mathrm{NPP}, j}}{\delta C_{\mathrm{L}, j}}-\frac{\delta F_{\mathrm{C}, \mathrm{NPP}, j}}{\delta C_{\mathrm{R}, 1, j}}\right] \\
& H\left[\frac{\delta F_{\mathrm{C}, \mathrm{NPP}, j}}{\delta C_{\mathrm{L}, j}}-\frac{\delta F_{\mathrm{C}, \mathrm{NPP}, j}}{\delta C_{\mathrm{R}, 2, j}}\right], \\
& \alpha_{\mathrm{R}, 1, j}=H\left[\frac{\delta F_{\mathrm{C}, \mathrm{NPP}, j}}{\delta C_{\mathrm{R}, 1, j}}-\frac{\delta F_{\mathrm{C}, \mathrm{NPP}, j}}{\delta C_{\mathrm{L}, j}}\right] \\
& H\left[\frac{\delta F_{\mathrm{C}, \mathrm{NPP}, j}}{\delta C_{\mathrm{R}, 1, j}}-\frac{\delta F_{\mathrm{C}, \mathrm{NPP}, j}}{\delta C_{\mathrm{R}, 2, j}}\right], \\
& \alpha_{\mathrm{R}, 2, j}=H\left[\frac{\delta F_{\mathrm{C}, \mathrm{NPP}, j}}{\delta C_{\mathrm{R}, 2, j}}-\frac{\delta F_{\mathrm{C}, \mathrm{NPP}, j}}{\delta C_{\mathrm{L}, j}}\right] \\
& H\left[\frac{\delta F_{\mathrm{C}, \mathrm{NPP}, j}}{\delta C_{\mathrm{R}, 2, j}}-\frac{\delta F_{\mathrm{C}, \mathrm{NPP}, j}}{\delta C_{\mathrm{R}, 1, j}}\right],
\end{aligned}
$$

where $H$ is the Heaviside step function, the value of which is 0 for a negative argument and 1 for a positive argu- 
ment. Partial derivatives in Eqs. (30)-(32) are readily evaluated from analytically differentiating $F_{\mathrm{C}, \mathrm{NPP}, j}$ with respect to each plant carbon pool.

For trees, the total allocation to leaves and wood is partitioned, such that a target ratio of leaf area to sapwood area, $k_{\mathrm{LA}: \mathrm{SA}}$, is maintained:

$$
\frac{\left(C_{\mathrm{L}, \mathrm{w}}+\alpha_{\mathrm{L}, \mathrm{w}} F_{\mathrm{C}, \text { growth,w }}-k_{\mathrm{L}, \mathrm{w}} C_{\mathrm{L}, \mathrm{w}}\right) A_{\mathrm{SL}, \mathrm{w}}}{A_{\text {sapwood }}} \leq k_{\mathrm{LA}: \mathrm{SA}},
$$

where $A_{\mathrm{SL}, \mathrm{w}}$ is the specific leaf area for woody vegetation (see Eq. 1 below).

\subsection{Vegetation cover}

The vegetation cover fraction or green-leaf cover $n$ (dimensionless, between 0 and 1 ) is assumed equal to the fraction of absorbed photosynthetically active radiation (fPAR) and related to leaf area index, $L$, by

$v_{\text {tree }}=1-\exp \left(-c_{\text {Ext }} K_{\text {clump }} \Lambda_{\mathrm{w}}\right)$

and

$v_{\mathrm{g}}=\left(1-v_{\mathrm{g}}\right)\left(1-\exp \left(-c_{\mathrm{Ext}} \Lambda_{\mathrm{g}}\right)\right)$,

where $c_{\text {Ext }}$ is the exponential light extinction coefficient in the canopy (assumed here the same for trees and grass), and $K_{\text {clump }}$ is a crown clumping factor related to crown projected cover, $A_{\mathrm{c}}$, by (Haverd et al., 2012)

$K_{\text {Clump }}=\min \left[A_{\mathrm{c}}\left(1.0-\exp \left(-c_{\text {Ext }} \Lambda_{w} / A_{\mathrm{c}}\right)\right) /\right.$

$\left.\left(c_{\text {Ext }} \Lambda_{w}\right), 1.0\right]$

as computed within the POP module.

Leaf area index is related to the leaf carbon pool and specific leaf area $A_{\mathrm{SL}}\left[\mathrm{cm}^{2} \mathrm{~g}(\mathrm{DW})^{-1}\right]$ by

$\Lambda_{j}=0.0024 \frac{\mathrm{g}(\mathrm{DW}) \mathrm{cm}^{-2}}{\mathrm{molCm}^{-2}} A_{\mathrm{SL}, j} C_{\mathrm{L}, j}$.

For woody vegetation, specific leaf area is known to increase with mean annual precipitation $\left(P, \mathrm{~mm} \mathrm{yr}^{-1}\right)$ along the NATT as (Schulze et al., 1998)

$A_{\mathrm{SL}, \mathrm{w}}=2.0+0.025 P$.

\subsection{Woody biomass turnover and tree demography feedbacks on carbon uptake}

Woody biomass turnover due to resource-limitation mortality and disturbance mortality (including fire mortality) is computed by coupling HAVANA to the POP module for tree demography and landscape heterogeneity mediated by disturbance. POP has been fully described elsewhere (Haverd et al., 2014), except for updates used in this work, relating to the feedbacks of structure on function, which are documented in Appendix A.

\section{Study site and observational data}

The NATT is a $1000 \mathrm{~km}$ transect (Hutley et al., 2011), with a systematic decline in mean annual rainfall (Grant et al., 2008; Jones et al., 2009) with distance ( $1 \mathrm{~mm}$ per $\mathrm{km})$ from the northern coast of the Northern Territory, Australia. As in Haverd et al. (2013b), we represent the gradients in rainfall (Fig. 2ii) and fire regime (Fig. 2iii) of the NATT transect by selecting 1000 random $0.05^{\circ} \times 0.05^{\circ}$ grid cells from an area bounded by $\left(19.95^{\circ} \mathrm{S}, 11.4^{\circ} \mathrm{S}, 130.0^{\circ} \mathrm{E}, 134.5^{\circ} \mathrm{E}\right.$; Fig. 2i). The NATT is characterized by largely intact savanna vegetation. In the north of the region (mean annual precipitation $>600 \mathrm{~mm}$ ), the dominant vegetation is tropical savanna (overstorey of evergreen Eucalyptus and Corymbia tree species, and an understorey dominated by $\mathrm{C} 4$ grasses), while Acacia woodlands, shrublands and hummock grasslands become increasingly prominent at the southern, semiarid extreme (Hutley et al., 2011). The vegetation is subjected to fire regularly (once every 2 to 7 years, Fig. 2ii; data derived from Craig et al., 2002). The fraction of early dry-season (pre-August) fires follows a similar latitudinal pattern to the fire frequency, which is an effect of fire management. Fire timing is a predictor of fire intensity, with late-season fires generally being significantly more intense as fuels accumulate and cure and weather becomes more extreme (Williams et al., 1998).

\subsection{Driving data}

HAVANA was forced using gridded meteorological data and soil properties at $0.05^{\circ}$ spatial resolution, which are described fully in Haverd et al. (2013a). Briefly, meteorological data comprise daily gridded rainfall, temperature, and solar irradiance for the period 1900-2013, current at March 2014, from the Bureau of Meteorology's Australian Water Availability Project data set (BoM AWAP; Grant et al., 2008; Jones et al., 2009), with temporal gap filling using climatologies from the same data set. Soil information is taken from the McKenzie and Hook (1992) and McKenzie et al. (2000) interpretations of the 725 principal profile forms (soil types) mapped in the Digital Atlas of Australian Soils (Northcote et al., 1960, 1975).

\subsection{Data for model calibration and validation}

\section{Calibration data}

Monthly estimates of GPP and ET from five flux tower sites (Table 2 and located in Fig. 2i) were obtained from eddy covariance data sets that were quality assured and quality controlled using the OzFlux standard processing protocol OzFluxQCv2.8.5 (Eamus et al., 2013). Gaps in missing data were filled, and GPP was resolved from net ecosystem exchange (NEE) using a new processing package called DINGO (Dynamic INtegrated Gap filling and partitioning for OzFlux). 

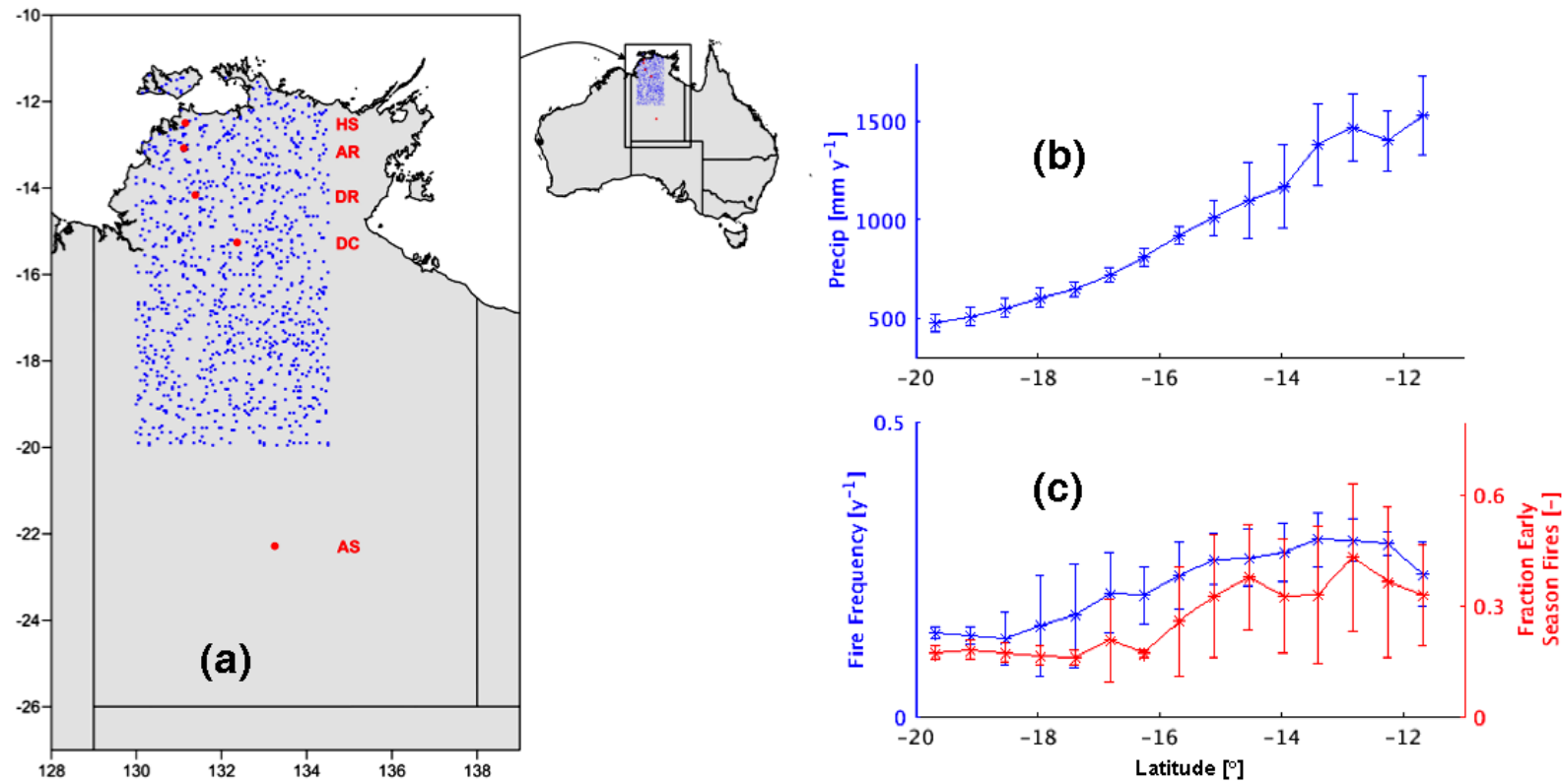

Figure 2. (a) Map of 1000 points representative of the study area, and locations of flux sites (red dots) for use in calibration/validation. Flux site abbreviations are given in Table 2. (b) Latitudinal variation in mean annual precipitation (1900-2013). (c) Latitudinal variation in fire frequency and fraction of fires occurring in the early part of the dry season (pre-August; 1989-2011). Each point represents a spatial average across $\sim 65$ points lying within a latitude bin of width $0.57^{\circ}$, with error bars representing 1 standard deviation.

Table 2. Locations and characteristics of OzFlux sites (after Hutley et al., 2011).

\begin{tabular}{|c|c|c|c|c|c|}
\hline Site & Coordinates & Reference & Ecosystem & Dominant vegetation & Data period \\
\hline $\begin{array}{l}\text { 1. Howard } \\
\text { Springs (HS) }\end{array}$ & $\begin{array}{r}12.4952^{\circ} \mathrm{S} \\
131.1501^{\circ} \mathrm{E}\end{array}$ & $\begin{array}{l}\text { (Beringer et al., 2003), } \\
\text { (Beringer et al., 2011) }\end{array}$ & $\begin{array}{l}\text { Open-forest } \\
\text { savanna }\end{array}$ & $\begin{array}{l}\text { Eucalyptus miniata and E. tetrodonta, } \\
\text { Sorghum intrans, S. plumosum, Heteropogon triticeus } \\
\text { grassy understorey }\end{array}$ & $01 / 2001-12 / 2013$ \\
\hline 2. Adelaide & $13.0769^{\circ} \mathrm{S}$ & (Beringer et al., 2007) & Open-forest & $\begin{array}{l}\text { E. tectifica, Planchonia careya, } \\
\text { Chrysopogon fallax grassy understorey }\end{array}$ & \\
\hline River (AR) & $131.1178^{\circ} \mathrm{E}$ & (Beringer et al., 2011) & savanna & $\begin{array}{l}\text { Buchanania obovata woodland savanna, Sorghum spp., } \\
\text { Chrysopogon fallax grassy understorey }\end{array}$ & 01/2007-05/2009 \\
\hline $\begin{array}{l}\text { 3. Daly River } \\
\text { savanna (DR) }\end{array}$ & $\begin{array}{r}14.1592^{\circ} \mathrm{S} \\
131.3833^{\circ} \mathrm{E}\end{array}$ & (Beringer et al., 2011) & $\begin{array}{l}\text { Woodland } \\
\text { savanna }\end{array}$ & $\begin{array}{l}\text { E. tetrodonta, } \text { C. latifolia, and } \\
\text { Terminalia grandiflora, Sorghum } \mathrm{sp.} \\
\text { H. triticeus }\end{array}$ & $01 / 2007-12 / 2013$ \\
\hline $\begin{array}{l}\text { 4. Dry } \\
\text { Creek (DC) }\end{array}$ & $\begin{array}{r}15.2588^{\circ} \mathrm{S} \\
132.3706^{\circ} \mathrm{E}\end{array}$ & (Beringer et al., 2011) & $\begin{array}{l}\text { Woodland } \\
\text { savanna }\end{array}$ & $\begin{array}{l}\text { E. tetrodonta, E. dichromophloia, C. terminalis, } \\
\text { S. intrans, S. plumosum, Themeda triandra } \\
\text { and C. fallax }\end{array}$ & $01 / 2010-06 / 2013$ \\
\hline $\begin{array}{l}\text { 5. Alice } \\
\text { Springs (AS) }\end{array}$ & $\begin{array}{l}22.283^{\circ} \mathrm{S} \\
133.249^{\circ} \mathrm{E}\end{array}$ & (Cleverly et al., 2013) & $\begin{array}{l}\text { Acacia } \\
\text { woodland }\end{array}$ & Acacia aneura & 09/2010-12/2013 \\
\hline
\end{tabular}

DINGO applies a linear interpolation to gaps of less than $2 \mathrm{~h}$, and uses the following methods for gaps longer than $2 \mathrm{~h}$. For temperature, humidity, pressure, precipitation, and wind speed, DINGO searches for the 10 closest Australian $\mathrm{Bu}-$ reau of Meteorology (BoM) monitoring sites from a localized database and gap-fills using data from the site for which correlation with site data is the highest. Gaps in incoming solar radiation gaps are filled using solar exposure data, derived by the BoM from satellite imagery, while reflected solar radiation is filled using the MODIS albedo product. Soil moisture and temperature gaps are filled from half-hourly outputs from a biogeochemical LSM, constrained by observations of land-atmosphere fluxes, biomass, streamflow, and remotely sensed vegetation cover (Haverd et al., 2013a). A feedforward artificial neural network (ANN), described in Beringer et al. (2007), is used to gap-fill NEE and sensible, latent, and soil heat fluxes.

DINGO estimates GPP as NEE minus ecosystem respiration $\left(R_{\mathrm{e}}\right)$, with $R_{\mathrm{e}}$ estimated as follows. During the night, $\mathrm{CO}_{2}$ fluxes are assumed to equal $R_{\mathrm{e}}$, as no photosynthesis occurs. It is also assumed that NEE, being biologically determined, is independent of atmospheric turbulence and remains constant above a friction velocity $\left(u^{*}\right)$ threshold (Goulden et al., 1996), also assuming that stored $\mathrm{CO}_{2}$ is drained com- 


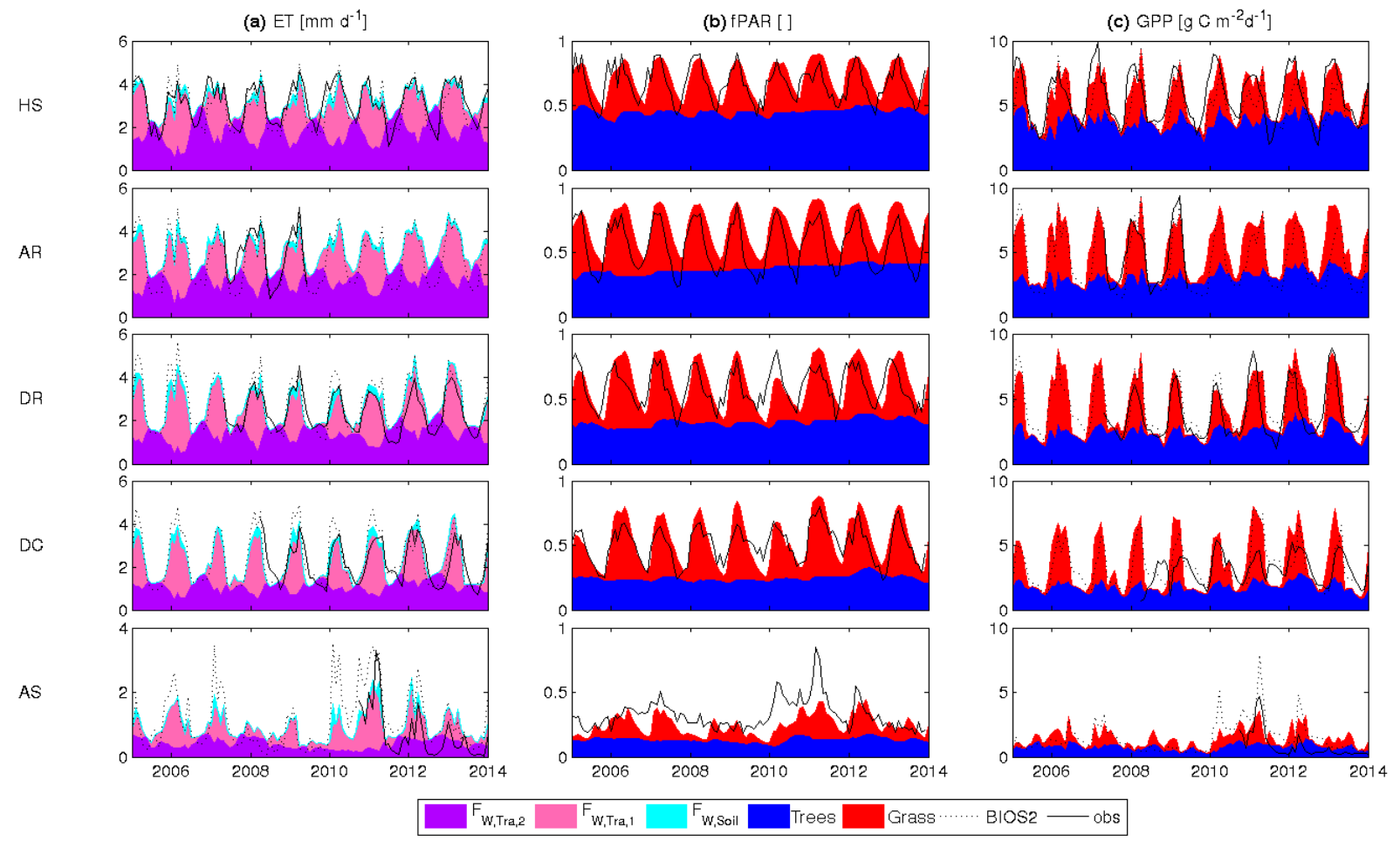

Figure 3. Monthly (2005-2013) time series of (a) ET, (b) fPAR, and (c) GPP at five flux stations: HAVANA-POP (stacked plots), BIOS2 (full biogeochemical model with prescribed vegetation cover), and observations. HAVANA-POP ET is partitioned into soil evaporation and transpiration from each of the upper (1) and lower (2) soil layers. HAVANA-POP fPAR and GPP are partitioned into tree and grass components. Flux site abbreviations (left of figure) are given in Table 2.

pletely from beneath the canopy before re-initiation of turbulence (Aubinet, 2008). This last assumption is likely to be violated at the southernmost site, Alice Springs (Cleverly et al., 2013). Based on these assumptions, we used a $u^{*}$ threshold for selecting nights of adequate ventilation to determine the respiration component of carbon flux. The $u^{*}$ threshold applied is based on Reichstein et al. (2005), where the $u^{*}$ filtering data set is split into six equal sample size temperature classes, and into $20 u^{*}$ classes within each temperature class. When the $u^{*}$ value falls below the threshold, DINGO removes the value of NEE during that half-hour and the subsequent half-hour. The maximum $u^{*}$ threshold and gap-filled soil moisture, soil temperature, air temperature, and normalized difference vegetation index (NDVI) variables are inputs to an ANN for calculating $R_{\mathrm{e}}$.

A monthly time series of fPAR for January 1982 to December 2013 was derived from the third generation (NDVI3g) of the GIMMS NDVI time series (Tucker et al., 2005; Zhu et al., 2013). A monthly maximum composite was created from the original 15 -day series, and the data were resampled from the original $0.0833^{\circ}$ resolution $(8 \mathrm{~km})$ to $0.05^{\circ}$ $(5 \mathrm{~km})$. NDVI values from 0.1 (bare ground) to 0.75 (full cover) were linearly rescaled between 0 and 1 to represent vegetation fractional cover. For calibration, we used 20002013 data at the locations of the flux sites (Table 1).

\section{Validation data}

For model evaluation, we used predictive empirical models describing the decline of basal area and projected foliage cover with rainfall, developed by Williams et al. (1996) from a data set of $\sim 1000$ quadrats (each $20 \mathrm{~m} \times 20 \mathrm{~m}$ ) lying north of $18^{\circ} \mathrm{S}$ within the Northern Territory. We also utilized observations reported by Sea et al. (2011) of dry-season (September 2008) tree leaf area index (LAI) based both on digital hemispheric photography (DHP) and the MODIS Collection 5 (MODC5) remote-sensing LAI product. Additionally we used monthly fPAR (as described in subsection "Calibration data" of Sect. 3.2 above) along the entire rainfall gradient.

\section{Model-data fusion}

We calibrated HAVANA parameters by optimization against monthly observations of ET, GPP, and fPAR, subject to prior constraints. The parameters subject to calibration are shown in Table 1. The search algorithm was the LevenbergMarquardt method implemented in the PEST software package (Doherty, 2004). The cost function to be minimized was the weighted sum of squared residuals, $\Phi=\sum_{i} w_{i}^{2} r_{i}^{2}$, 
(a) HAVANA-POP: Dynamic phenology and vegetation
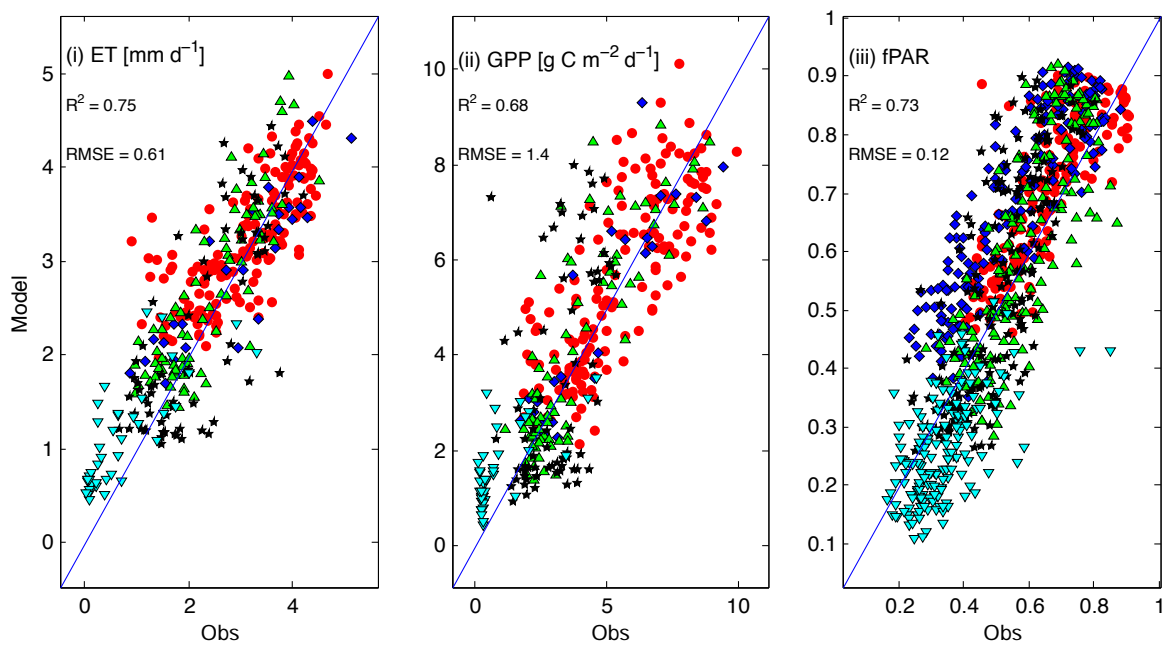

(b) Full biogeochemical model: prescribed phenology and vegetation
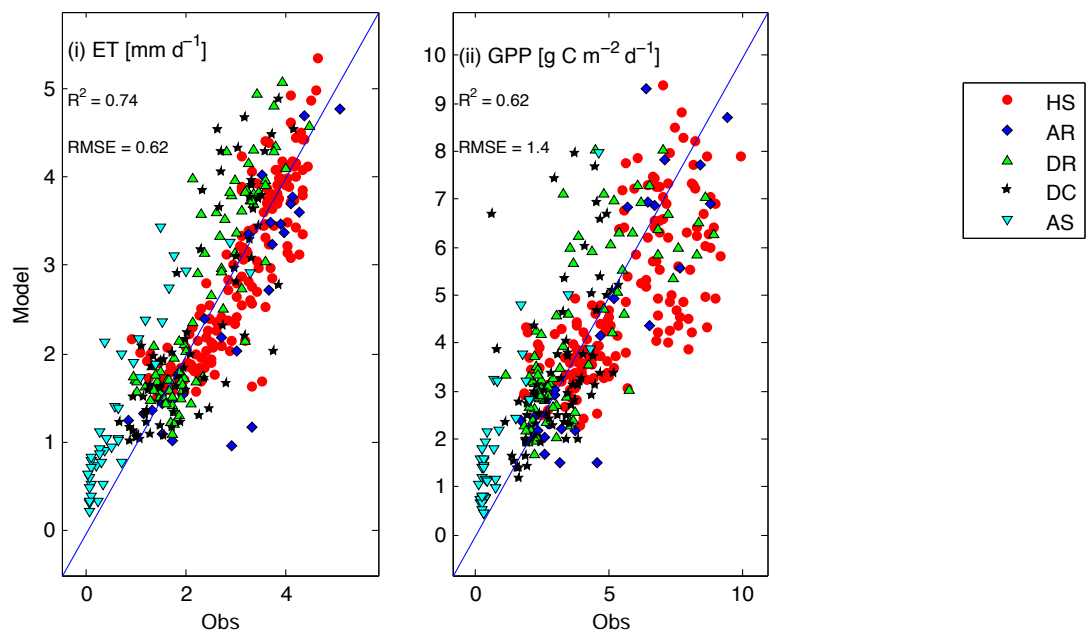

Figure 4. Scattergrams of model predictions vs. observations of monthly values at 5 flux sites of (i) ET, (ii) GPP, and (iii) fPAR. (a) HAVANAPOP and (b) CABLE in BIOS2, a full biogeochemical model with prescribed phenology and vegetation cover.

where the residual $r_{i}$ can be either the residual between a model prediction and corresponding observation or the residual between prior and posterior variables. Relative observation weights $\left(w_{i}\right)$ were set such that each observation data type and each prior constraint contributed equally to the prior cost function.

Prior constraints consisted of estimates of leaf and fine root carbon pools at Howard Springs. We assume prior estimates of time-averaged leaf carbon to be 50 and $100 \mathrm{gCm}^{-2}$ for grassy and woody vegetation, respectively, and a ratio of time-averaged fine root mass to leaf mass of 2. Leaf carbon estimates are based on Chen et al. (2003). The ratio of fine root to leaf mass is a very rough estimate, as estimates of peak fine root mass in northern Australian tropical savannas are divergent: $1800 \mathrm{~g} \mathrm{C} \mathrm{m}^{-2}$ (range $1050-4050 \mathrm{~g} \mathrm{C} \mathrm{m}^{-2}$; Janos et al., 2008), $1300 \mathrm{~g} \mathrm{C} \mathrm{m}^{-2}$ (Chen et al., 2004), and
$70 \mathrm{~g} \mathrm{C} \mathrm{m}^{-2}$ (Chen et al., 2002; assuming a specific root length of $10 \mathrm{~m} \mathrm{~g}^{-1}$, and possibly a factor of 10 too low due to units conversion error; Janos et al., 2008).

\section{Results}

\subsection{Calibration}

We assessed the calibrated HAVANA predictions of monthly fluxes of ET and GPP, as well as monthly mean remotely sensed fPAR. Time series of the three modelled variables for each flux site are shown in Fig. 3 as coloured patches, with colour coding to represent the flux partitioning between transpiration from upper and lower soil and soil evaporation (ET) and between tree and grass components (fPAR and GPP). The observed quantities are also shown along with a bench- 

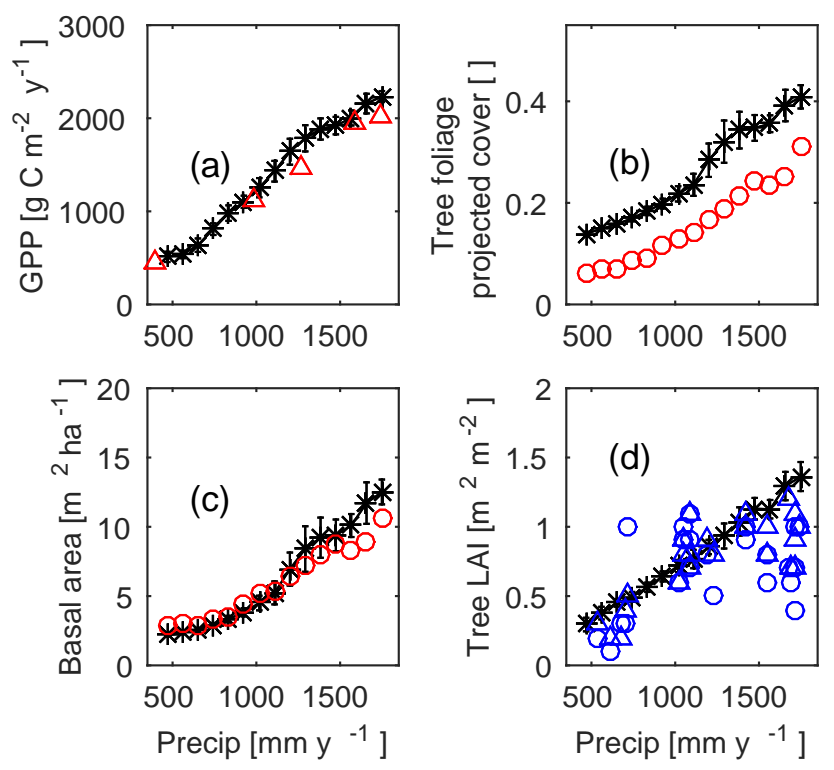

\begin{tabular}{|ll|}
\hline * & HAVANA-POP \\
$\triangle$ & Flux data \\
0 & Williams et al. 1996 \\
0 & Sea et al. 2011 (DHP) \\
$\triangle$ & Sea et al. 2011 (MODC5)
\end{tabular}

Figure 5. Time-averaged (1964-2013) HAVANA-POP output variables: variation with rainfall and comparison with observationbased estimates. (a) Gross primary production (combined tree and grass components) and comparison with mean annual GPP from flux data (averaged over observation period); (b) annual average tree foliage projected cover and comparison with Williams et al. (1996); (c) tree basal area and comparison with Williams et al. (1996); and (d) dry-season tree LAI (September 2008) and comparison with Sea et al. (2011) estimated from digital hemispheric photography (DHP) and the MODIS Collection 5 product (MODC5).

mark, i.e. a state-of-the-art biogeochemical LSM (CABLE, as implemented in BIOS2; Haverd et al., 2013a), forced using LAI derived from the GIMMS-3g fPAR product (Zhu et al., 2013), and calibrated here against GPP and ET from the five flux sites. ET, fPAR, and GPP determined from HAVANA-POP increasingly matched observations toward the northern end of the NATT, where a more predictable seasonal cycle was observed than at the southernmost semi-arid site (Fig. 4). Even without being supplied external vegetation cover information, our new HAVANA model performed comparably to the benchmark (BIOS2) for monthly GPP and ET, based on the $R^{2}$ values and RMSE scores (Fig. 4). There was a tendency in HAVANA and BIOS2 to under-predict ET (slope > 1), whereas the modelled range in GPP closely matched the observed range (Fig. 4). While ET, and to a lesser extent GPP, was under-predicted by BIOS2 at Howard Springs, the bias was not apparent in the HAVANA results (Fig. 4). Both models over-predict the small values of ET and GPP at the Alice Springs site (Fig. 4). HAVANA soil evaporation is a small proportion of ET at all sites.

\subsection{Evaluation}

We evaluated the performance of HAVANA-POP along the entire rainfall gradient (Fig. 5). Each model point represents a spatial average across $\sim 65$ points lying within a latitude bin of width $0.57^{\circ}$, with error bars representing 1 standard deviation. The model replicates observed variations with rainfall of GPP, foliage projective cover, tree basal area, and dry-season tree LAI along the transect. Modelled tree foliage projective cover is higher than the observation-based estimates by about 0.06 . This likely reflects a bias between the observation-based estimates and the satellite-based fPAR that was used for calibration.

\subsection{HAVANA dynamics along the NATT}

Figure 6a and $\mathrm{b}$ illustrate the dynamics of key HAVANA variables from north (top row) to south (bottom row) along the NATT. Soil moisture (Fig. 6ai) shows strong seasonality in the top layer, which is smoothed out in the lower layer, resulting in respective seasonal and persistent transpiration (root water extraction) from the two layers (Fig. 6aii). This leads to woody vegetation cover persisting throughout the year (Fig. 6aiii-iv) and only small seasonal fluctuations in associated GPP (Fig. 6av), compared with grassy vegetation cover, which is completely absent by the late dry season. The decline in fPAR southward along the NATT accords well with satellite observations (Fig. 6aiv), as does the interannual variability, which is largely absent at the northern end of the NATT and clearly evident below $970 \mathrm{~mm}$ mean annual precipitation.

Grassy vegetation is characterized by significant temporal shifts in NPP and growth, leading to large changes in the NSC store (Fig. 6bi). This ability for growth to draw on NSC reserves is critical for rapid production of resource uptake surfaces (leaves and roots) at the beginning of the wet season (Fig. 6biii). The change in storage flux (relative to NPP) increases down the transect as both woody and grassy vegetation become more reliant on the NSC pool for growth in times of stress (Fig. 6bi-ii). For grass, root carbon increases with aridity relative to leaf carbon. This is less evident for woody vegetation, because leaf carbon in woody vegetation is also influenced by a gradient in specific leaf area (Eq. 1). Allocation patterns for grass (Fig. 6bv) show an increasing fine root component as aridity increases down the transect, with temporal dynamics dictated by whether fine roots or leaves are limiting NPP (Eq. 30-31). (These are monthly averaged C-allocation coefficients, which do not necessarily sum to 1 because allocation coefficients are zero when growth is zero.) For trees (Fig. 6bvi), allocation to surface roots occurs in the early wet season, when soil moisture in the upper layer exceeds that in the lower layer. Thus tree and grass roots compete in the surface layer. When soil moisture is plentiful (e.g. 2011), root growth is small and the remainder is partitioned between stems and leaves (Fig. 6bvi). Leaf 

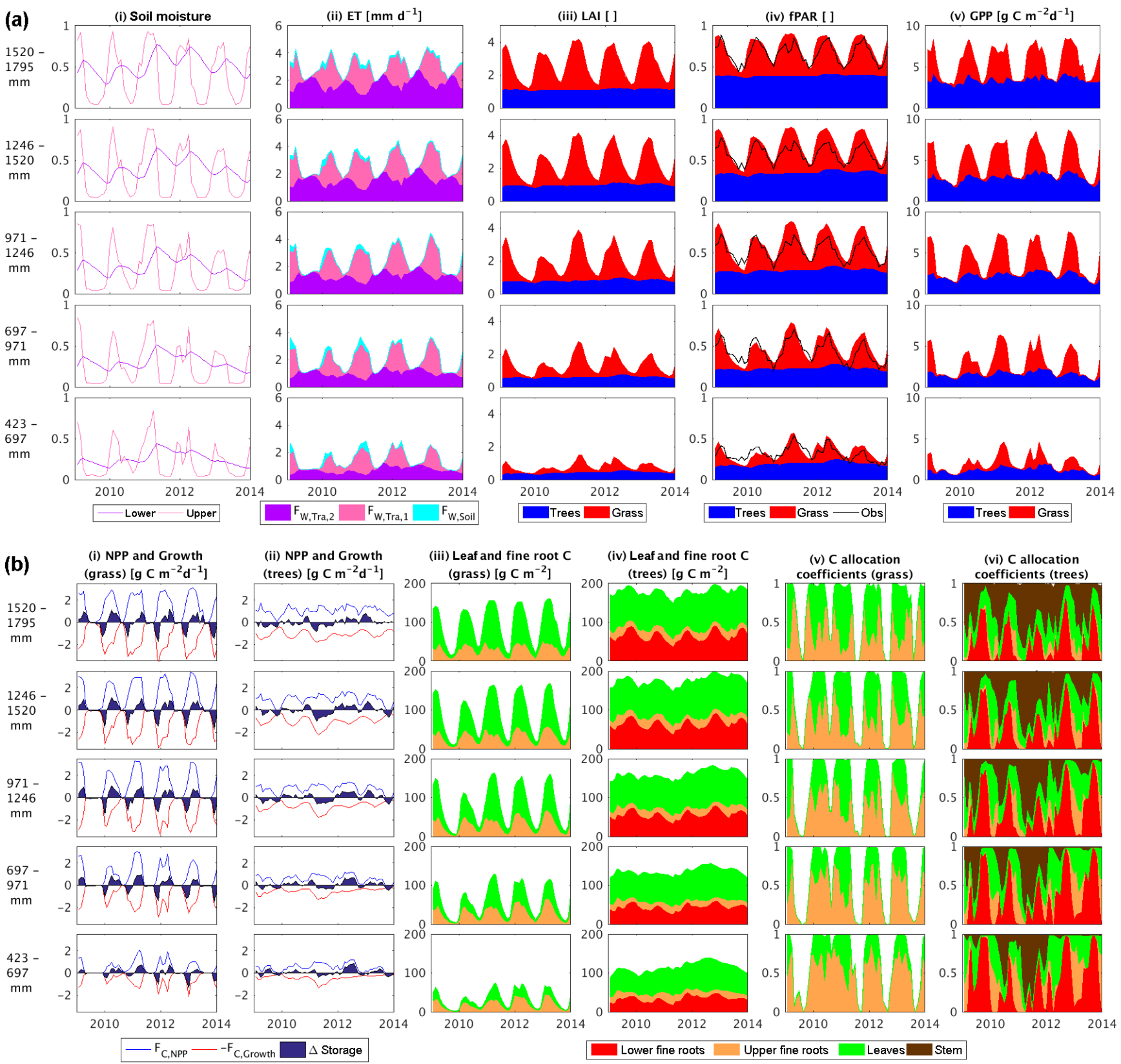

Figure 6. (a) Monthly time series (2009-2014) of (i) soil moisture ( $w_{1}$ and $\left.w_{2}\right)$, (ii) ET, (iii) leaf area index (LAI), (iv) fPAR, and (v) GPP, as predicted by HAVANA-POP. Corresponding observed fPAR is also shown. Each row represents a spatial average over the randomly sampled grid cells (Fig. 2a) falling within the range of mean annual precipitation shown on the left. (b) Monthly mean time series (2009-2014) of (i) NPP, growth, and change in storage (grass); (ii) NPP, growth, and change in storage (trees); (iii) leaf and fine root carbon pools (grass); (iv) leaf and fine root carbon pools (trees); (v) C allocation coefficients to leaves and fine roots (grass); and (vi) $\mathrm{C}$ allocation coefficients to leaves, fine roots, and stems (trees). Spatial aggregation is the same as in Fig. 6a. 
carbon is constrained by sapwood area (Eq. 1), leading to periods of high allocation to stems in wet periods.

\section{Discussion}

There is ongoing debate about the mechanisms governing tree and grass cover and maintaining the stability of savanna ecosystems relative to grassland or closed woody ecosystems (Bond, 2008; Torello-Raventos et al., 2013). While it is widely acknowledged that both resource limitation (especially water) and disturbance (fire and grazing) may control tree cover, their roles differ along environmental gradients and between continents (Africa, Australia, and South America), to the extent that Lehmann et al. (2014) claimed that "a single model cannot adequately represent savanna woody biomass across these regions". Sankaran et al. (2005) found woody carrying capacity in African savannas to be limited by rainfall, but that savannas were typically held below woody carrying capacity by fire or grazing. Supporting the influential role of disturbance, Bond et al. (2005) used a dynamic vegetation model to infer that fire suppression has the potential to convert vast areas of $\mathrm{C} 4$ grassland and savannas to forests, roughly doubling the global area covered by forest. Sea and Hanan (2012) highlight the importance of self-thinning of smaller trees as they compete with grass for resources, in contrast to the Walter hypothesis (Ward et al., 2013) that tree-grass co-existence is made possible by separation of the rooting niche. While root partitioning is important in controlling relative performance of trees and grasses (e.g. Kulmatiski and Beard, 2013), there is good evidence that long-term stand dynamics are modulated by lifehistory disturbance interactions on demography (Higgins et al., 2000).

In Australian savannas (in contrast to other continents), Bond (2008) noted a roughly linear relationship between mean annual precipitation and tree cover, indicative of a stronger limitation by water availability and less impact from fire given the remarkable fire tolerance of the dominant woody genera of Australian savanna, Eucalyptus, and Corymbia (Lawes et al., 2011). Murphy et al. (2015) suggested that fire impacts controlling Eucalyptus and Corymbia woody cover have been exaggerated in northern Australian savanna, with intraspecific competition for limited water and nutrient resources a far stronger driver of cover.

Our findings support the view that Australian savannah tree cover is primarily controlled by availability of soil resources rather than disturbance. Simulated tree cover emerges from the balance between production (controlled by resource availability) and turnover (controlled by both resource availability and the frequency and intensity of disturbance). In our simulations for Australia, a high proportion of biomass loss was attributable to resource limitation. Of the total biomass lost to mortality, $68 \%$ was attributable to resource limitation at the wet northern end of the NATT, increasing to $84 \%$ at the arid southern end. The remaining minority of biomass turnover was attributable to disturbance loss, largely from fire. We did not explicitly consider native or introduced grazers or browsers; however, these represent a minor disturbance agent compared with fire in northern Australia (Murphy et al., 2015). The approach of HAVANA-POP remains valid for regions in which savannah vegetation structure is controlled by the disturbance regime.

\section{Future prospects}

The principles encoded in HAVANA-POP have been demonstrated to suffice as a "single model" to account for savanna tree cover for the case of Australia. However, the model in its current form has limitations, warranting further development for use in carbon-water-nutrient cycle modelling. For example, (i) nutrient resources are not accounted for; (ii) fire frequency is prescribed; (iii) leaves have a fixed turnover rate, which may explain, for example, the lack of modelled seasonality in tree vegetation cover (Fig. 6aiv), known from observations to have an amplitude of about $30 \%$ at the northern end of the transect (Chen et al., 2003); and (iv) soil evaporation (Fig. 4i) is low compared with limited observations (e.g. Hutley et al., 2000) observed soil evaporation fluxes that accounted for $50 \%$ of total evapotranspiration during the wet season at Howard Springs).

To overcome the above limitations, and to test the HAVANA principles of coupled allocation-phenology describing savannas globally, future work will entail implementation of these principles within a full biogeochemical LSM, coupled to the POP module for tree demography and landscape heterogeneity (e.g. CABLE-POP; Haverd et al., 2014). In particular we propose implementing formulations developed here for growth (Eq. 1), NSC dynamics via coupling of growth and NPP (Eq. 1), and dynamic C allocation to maximize long-term NPP (Eqs. 1-1), while maintaining sufficient sapwood cross-sectional area to support leaf transpiration (Eq. 1). Such an implementation would require the following of the (modified) biogeochemical model: (i) root water extraction dependence on root carbon, (ii) association of root carbon with vertical structure of soil moisture stores, and (iii) partial derivatives of NPP (and hence GPP) with respect to plant carbon stores. Since GPP in the biogeochemical model may not be analytically differentiable, we suggest running the HAVANA GPP model (Eq. 1) in parallel with the full GPP model at daily timescale and with key parameters (water use and light use efficiencies) supplied by the full model at each daily time step.

\section{Conclusions}

We have shown that HAVANA-POP predicts tree-grass partitioning along a wide rainfall gradient within a biozone of the Australian savanna belt. The model behaviour emerges 
from complex feedbacks (Fig. 1) between the plant physiology and vegetation dynamics, mediated by shifting aboveversus below-ground resources, and not from imposed hypotheses about the controls on tree-grass co-existence. 


\section{Appendix A: Updates to the POP module}

POP simulates woody ecosystem stand dynamics, demography, and disturbance-mediated heterogeneity. In previous work, POP has been coupled to the CABLE land surface scheme (Wang et al., 2011) and demonstrated to successfully replicate both the effects of rainfall and fire disturbance gradients on vegetation structure along the NATT (Haverd et al., 2013b) and the leaf-stem allometric relationships derived from global forest data (Haverd et al., 2014).

\section{POP coupling}

In the above-mentioned applications, the CABLE-POP coupling consisted of just two exchanges: (i) stem NPP passed from the host LSM to POP and (ii) woody biomass turnover returned from POP to the host LSM. In contrast, in the current work, the HAVANA-POP coupling also includes the return of sapwood area and sapwood volume to HAVANA, where these variables respectively influence $\mathrm{C}$ allocation to leaves (Eq. 1) and autotrophic respiration (Eq. 1). Further, in previous applications of POP, LAI was exogenous, being imposed using remote sensing. In contrast, in the HAVANAPOP setup, LAI is endogenous, being computed from leaf carbon (Eq. 1). Figure A1 illustrates the HAVANA-POP coupling and key inputs and outputs.

\section{POP biomass partitioning amongst patches and cohorts}

Stem biomass increment for each patch, $\Delta C\left(\mathrm{kgC} \mathrm{m}^{-2}\right)$, is assumed equal to the grid-scale value, accumulated over the POP model time step $\Delta t$ (years).

In the original model, it was assumed that individuals capture resources in a varying proportion to their size, following a power relationship to biomass with an exponent $(s)$. On this basis, annual stem biomass increment was partitioned among cohorts in proportion to the population-weighted current biomass of individuals within each cohort:

$$
\frac{\Delta C_{y}}{\Delta t}=\frac{\left(C_{y} / N_{y}\right)^{s} N_{y}}{\sum\left(C_{i} / N_{i}\right)^{s} N_{i}} \frac{\Delta C}{\Delta t},
$$

where $C_{y}$ is the stem biomass summed across individuals of cohort $N_{y}$.

In the current work, gross primary production and autotrophic respiration are each passed from the host model to POP, and each is partitioned amongst patches and cohorts. Net resource uptake for each patch and cohort is evaluated as its gross primary production minus autotrophic respiration.

Gross resource uptake, $\Delta C_{\mathrm{g}}$, is partitioned amongst cohorts and patches in proportion to light interception, evaluated from vertical profiles of gap probabilities. These require the maximum leaf area, $\mathrm{LAI}_{\max }$, inherited from the host model to be partitioned amongst patches and cohorts in proportion to sapwood area in the $y$ th cohort and $p$ th patch

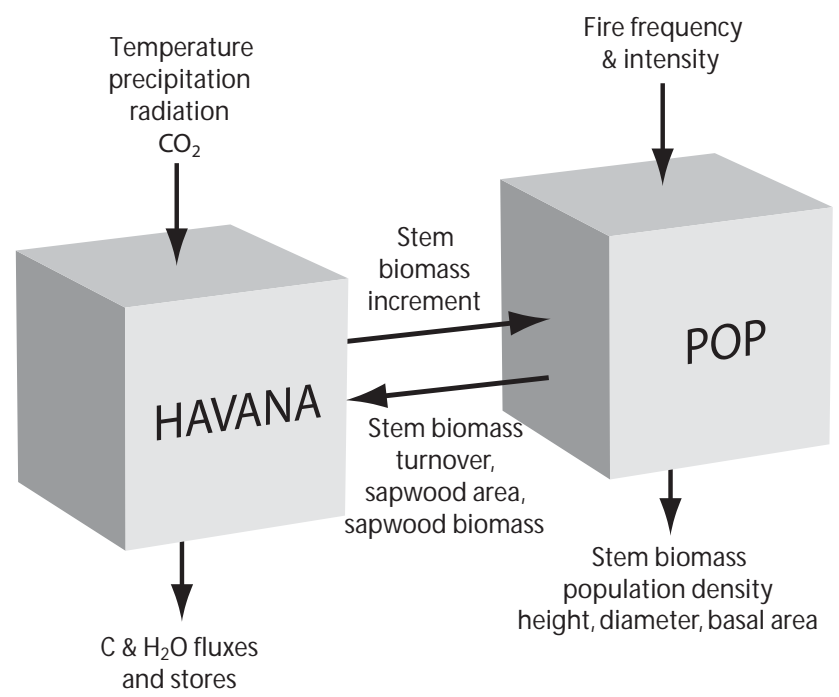

Figure A1. HAVANA-POP coupling.

$A_{\mathrm{s}, y, p}$

$\mathrm{LAI}_{\max , y, p}=N_{y, p} A_{\mathrm{s}, y, p} \frac{\sum_{x=1}^{y_{\max }} N_{x, p} A_{\mathrm{s}, x, p}}{\sum_{j=1}^{n_{p}} w_{j}\left(\sum_{x=1}^{y_{\max }} N_{x, j} A_{\mathrm{s}, x, j}\right)} \mathrm{LAI}_{\max }$.

Autotrophic respiration is also partitioned amongst cohorts and patches, with leaf and root carbon pools partitioned in proportion to LAI.

Stem biomass is the sum of sapwood $C_{\mathrm{s}, y, p}$ and heartwood components $C_{\mathrm{h}, y, p}$, with sapwood converted to heartwood at a rate $k_{\mathrm{s}}=0.05 \mathrm{yr}^{-1}$ :

$\begin{aligned} \frac{\Delta C_{\mathrm{s}, y, p}}{\Delta t} & =\frac{\Delta C_{y, p}}{\Delta t}-k_{\mathrm{s}} C_{\mathrm{s}, y, p}, \\ \frac{\Delta C_{\mathrm{h}, y, p}}{\Delta t} & =k_{\mathrm{s}} C_{\mathrm{s}, y, p} .\end{aligned}$

The sapwood area is related to sapwood biomass and tree dimensions by

$A_{\mathrm{s}, y, p}=\frac{\pi D_{y, p}^{2}}{4}-\frac{C_{y, p}-C_{\mathrm{s}, y, p}}{H_{y, p} N_{y, p} \rho_{w}}$.

Sapwood area is returned to the host model, where it constrains the relative $\mathrm{C}$ allocation to leaves and wood (Eq. 1). 
Acknowledgements. The contributions of V. Haverd and P. Briggs were made possible by the support of the Australian Climate Change Science Program. B. Smith acknowledges funding as an OCE Distinguished Visiting Scientist to the CSIRO Oceans \& Atmosphere Flagship, Canberra.

We are grateful to Ranga Myneni and Jian Bi for the supply of GIMMS NDVI3g updated to 2013, and to Randall Donohue for processing of these data for this study. This study is a contribution to the strategic research areas BECC and MERGE.

Edited by: B. Amiro

\section{References}

Ahlström, A., Raupach, M. R., Schurgers, G., Smith, B., Arneth, A., Jung, M., Reichstein, M., Canadell, J. G., Friedlingstein, P., Jain, A. K., Kato, E., Poulter, B., Sitch, S., Stocker, B. D., Viovy, N., Wang, Y. P., Wiltshire, A., Zaehle, S., and Zeng, N.: The dominant role of semi-arid ecosystems in the trend and variability of the land $\mathrm{CO}_{2}$ sink, Science, 348, 895-899, 2015.

Aubinet, M.: Eddy covariance $\mathrm{CO}_{2}$ flux measurements in nocturnal conditions: an analysis of the problem, Ecol. Appl., 18, 13681378,2008

Baudena, M., Dekker, S. C., van Bodegom, P. M., Cuesta, B., Higgins, S. I., Lehsten, V., Reick, C. H., Rietkerk, M., Scheiter, S., Yin, Z., Zavala, M. A., and Brovkin, V.: Forests, savannas, and grasslands: bridging the knowledge gap between ecology and Dynamic Global Vegetation Models, Biogeosciences, 12, 1833 1848, doi:10.5194/bg-12-1833-2015, 2015.

Beringer, J., Hutley, L., Tapper, N., Coutts, A., Kerley, A., and O'grady, A.: Fire impacts on surface heat, moisture and carbon fluxes from a tropical savanna in northern Australia, Int. J. Wildland Fire, 12, 333-340, 2003.

Beringer, J., Hutley, L. B., Tapper, N. J., and Cernusak, L. A.: Savanna fires and their impact on net ecosystem productivity in North Australia, Glob. Change Biol., 13, 990-1004, 2007.

Beringer, J., Hutley, L. B., Hacker, J. M., Neininger, B., and U, K. T. P.: Patterns and processes of carbon, water and energy cycles across northern Australian landscapes: From point to region, Agr. Forest Meteorol., 151, 1409-1416, 2011.

Bond, W. J.: What Limits Trees in C4 Grasslands and Savannas?, Annual Review of Ecology, Evolution, and Systematics, 39, 641659, 2008

Bond, W. J., Woodward, F. I., and Midgley, G. F.: The global distribution of ecosystems in a world without fire, New Phytol., 165, 525-538, 2005.

Chen, X., Eamus, D., and Hutley, L. B.: Seasonal patterns of soil carbon dioxide efflux from a wet-dry tropical savanna of northern Australia, Aust. J. Bot., 50, 43-52, 2002.

Chen, X., Hutley, L. B., and Eamus, D.: Carbon balance of a tropical savanna of northern Australia, Oecologia, 137, 405-416, 2003.

Chen, X., Eamus, D., and Hutley, L. B.: Seasonal Patterns of FineRoot Productivity and Turnover in a Tropical Savanna of Northern Australia, J. Trop. Ecol., 20, 221-224, 2004.

Choler, P., Sea, W., Briggs, P., Raupach, M., and Leuning, R.: A simple ecohydrological model captures essentials of seasonal leaf dynamics in semi-arid tropical grasslands, Biogeosciences, 7, 907-920, doi:10.5194/bg-7-907-2010, 2010.
Cleverly, J., Boulain, N., Villalobos-Vega, R., Grant, N., Faux, R., Wood, C., Cook, P. G., Yu, Q., Leigh, A., and Eamus, D.: Dynamics of component carbon fluxes in a semi-arid Acacia woodland, central Australia, J. Geophys. Res.-Biogeo., 118, 11681185, doi:10.1002/jgrg.20101, 2013.

Craig, R., Heath, B., Raisbeck-Brown, N., Steber, M., Marsden, J., and Smith, R.: The Distribution, Extent and Seasonality of Large Fires in Australia, April 1998-March 2000, as Mapped From NOAA-AVHRR Imagery, Department of the Environment and Heritage, Canberra, 2002.

Doherty, J.: PEST, Watermark numerical Computing, Townesville, 2004.

Donohue, R. J., McVicar, T. R., and Roderick, M. L.: Climaterelated trends in Australian vegetation cover as inferred from satellite observations, 1981-2006, Glob. Change Biol., 15, 10251039, 2009.

Eamus, D., Cleverly, J., Boulain, N., Grant, N., Faux, R., and Villalobos-Vega, R.: Carbon and water fluxes in an arid-zone Acacia savanna woodland: An analyses of seasonal patterns and responses to rainfall events, Agr. Forest Meteorol., 182-183, 225-238, 2013.

Franklin, O., Johansson, J., Dewar, R. C., Dieckmann, U., McMurtrie, R. E., Brannstrom, A., and Dybzinski, R.: Modeling carbon allocation in trees: a search for principles, Tree Physiol., 32, 648666, 2012.

Goulden, M. L., Munger, J. W., Song-Miao, F., Daube, B. C., and Wofsy, S. C.: Measurements of carbon sequestration by longterm eddy covariance: methods and a critical evaluation of accuracy, Glob. Change Biol., 2, 169-182, 1996.

Grant, I., Jones, D., Wang, W., Fawcett, R., and Barratt, D.: Meteorological and remotely sensed datasets for hydrological modelling: A contribution to the Australian Water Availability Project, Melbourne, Jan 9-11, 2008.

Haverd, V., Lovell, J. L., Cuntz, M., Jupp, D. L. B., Newnham, G. J., and Sea, W.: The Canopy Semi-analytic Pgap And Radiative Transfer (CanSPART) model: Formulation and application, Agr. Forest Meteorol., 160, 14-35, 2012.

Haverd, V., Raupach, M. R., Briggs, P. R., Canadell, J. G., Isaac, P., Pickett-Heaps, C., Roxburgh, S. H., van Gorsel, E., Viscarra Rossel, R. A., and Wang, Z.: Multiple observation types reduce uncertainty in Australia's terrestrial carbon and water cycles, Biogeosciences, 10, 2011-2040, doi:10.5194/bg-10-2011-2013, 2013a.

Haverd, V., Smith, B., Cook, G. D., Briggs, P. R., Nieradzik, L., Roxburgh, S. H., Liedloff, A., Meyer, C. P., and Canadell, J. G.: A stand-alone tree demography and landscape structure module for Earth system models, Geophys. Res. Lett., 40, 5234-5239, 2013b.

Haverd, V., Smith, B., Nieradzik, L. P., and Briggs, P. R.: A stand-alone tree demography and landscape structure module for Earth system models: integration with inventory data from temperate and boreal forests, Biogeosciences, 11, 4039-4055, doi:10.5194/bg-11-4039-2014, 2014.

Higgins, S. I., Bond, W. J., and Trollope, W. S.: Fire, resprouting and variability: a recipe for grass-tree coexistence in savanna, J. Ecol., 88, 213-229, 2000.

Hutley, L. B., O'Grady, A. P., and Eamus, D.: Evapotranspiration from Eucalypt open-forest savanna of Northern Australia, Funct. Ecol., 14, 183-194, 2000. 
Hutley, L. B., Beringer, J., Isaac, P. R., Hacker, J. M., and Cernusak, L. A.: A sub-continental scale living laboratory: Spatial patterns of savanna vegetation over a rainfall gradient in northern Australia, Agr. Forest Meteorol., 151, 1417-1428, 2011.

Janos, D. P., Scott, J., and Bowman, D. M. J. S.: Temporal and spatial variation of fine roots in a northern Australian Eucalyptus tetrodonta savanna, J. Trop. Ecol., 24, 177-188, doi:10.1017/S026646740800486, 2008.

Jones, D. A., Wang, W., and Fawcett, R.: High-quality spatial climate data-sets for Australia, Australian Meteorological and Oceanographic Journal, 58, 233-248, 2009.

Kulmatiski, A. and Beard, K. H.: Woody plant encroachment facilitated by increased precipitation intensity, Nature Climate Change, 3, 833-837, 2013.

Lawes, M., Richards, A., Dathe, J., and Midgley, J.: Bark thickness determines fire resistance of selected tree species from fire-prone tropical savanna in north Australia, Plant Ecol., 212, 2057-2069, 2011.

Lehmann, C. E., Anderson, T. M., Sankaran, M., Higgins, S. I., Archibald, S., Hoffmann, W. A., Hanan, N. P., Williams, R. J., Fensham, R. J., and Felfili, J.: Savanna vegetation-fire-climate relationships differ among continents, Science, 343, 548-552, 2014.

Lehmann, C. E. R., Prior, L. D., and Bowman, D. M. J. S.: Decadal dynamics of tree cover in an Australian tropical savanna, Austral Ecology, 34, 601-612, 2009.

Liu, Y. Y., van Dijk, A. I. J. M., de Jeu, R. A. M., Canadell, J. G., McCabe, M. F., Evans, J. P., and Wang, G.: Recent reversal in loss of global terrestrial biomass, Nature Climate Change, 5, 470-474, 2015.

Lloyd, J. and Taylor, J. A.: On the Temperature Dependence of Soil Respiration, Funct. Ecol., 8, 315-323, 1994.

Ma, X., Huete, A., Yu, Q., Coupe, N. R., Davies, K., Broich, M., Ratana, P., Beringer, J., Hutley, L. B., Cleverly, J., Boulain, N., and Eamus, D.: Spatial patterns and temporal dynamics in savanna vegetation phenology across the North Australian Tropical Transect, Remote Sens. Environ., 139, 97-115, 2013.

McDowell, N., Barnard, H., Bond, B., Hinckley, T., Hubbard, R., Ishii, H., Kostner, B., Magnani, F., Marshall, J., Meinzer, F., Phillips, N., Ryan, M., and Whitehead, D.: The relationship between tree height and leaf area: sapwood area ratio, Oecologia, 132, 12-20, 2002.

McKenzie, N. J. and Hook, J.: Interpretation of the Atlas of Australian Soils, Technical Report, CSIRO Division of Soils, Canberra, 94/1992, 1992.

McKenzie, N. J., Jacquier, D. W., Ashton, L. J., and Creswell, H. P.: Estimation of soil properties using the Atlas of Australian Soils, Canberra, 24 pp., 2000.

Murphy, B. P., Liedloff, A. C., and Cook, G. D.: Does fire limit tree biomass in Australian savannas?, Int. J. Wildland Fire, 24, 1, 2015.

Northcote, K. H., Beckmann, G. G., Bettenay, E., Churchward, H. M., Van Dijk, D. C., Dimmock, G. M., Hubble, G. D., Isbell, R. F., McArthur, W. M., Murtha, G. G., Nicolls, K. D., Paton, T. R., Thompson, C. H., Webb, A. A., and Wright, M. J.: Atlas of Australian Soils, Sheets 1 to 10 . With explanatory data, CSIRO Australia and Melbourne University Press, Melbourne, 1960.
Northcote, K. H., Hubble, G. D., Isbell, R. F., Thompson, C. H., and Bettenay, E.: A Description of Australian Soils, CSIRO Australia, 1975.

Poulter, B., Frank, D., Ciais, P., Myneni, R. B., Andela, N., Bi, J., Broquet, G., Canadell, J. G., Chevallier, F., Liu, Y. Y., Running, S. W., Sitch, S., and van der Werf, G. R.: Contribution of semiarid ecosystems to interannual variability of the global carbon cycle, Nature, 509, 600-603, 2014.

Priestley, C. H. B. and Taylor, R. J.: On the Assessment of Surface Heat Flux and Evaporation Using Large-Scale Parameters, Mon. Weather Rev., 100, 81-92, 1972.

Raupach, M. R.: Influences of local feedbacks on land-air exchanges of energy and carbon, Glob. Change Biol., 4, 477-494, 1998.

Raupach, M. R.: Equilibrium Evaporation and the Convective Boundary Layer, Bound.-Lay. Meteorol., 96, 107-142, 2000.

Raupach, M. R.: Combination theory and equilibrium evaporation, Q. J. Roy. Meteorol. Soc., 127, 1149-1181, 2001.

Raupach, M. R.: Dynamics and optimality in coupled terrestrial energy, water, carbon and nutrient cycles, in: Predictions in ungauged basins: international perspectives on the state of the art and pathways forward 2005, edited by: Franks, S. W. S. M., Takeuchi, K., Tachikawa, Y., 2005.

Raupach, M. R. R., Briggs, P. R., Haverd, V., King, E. A., Paget, M., and Trudinger, C. M.: Australian Water Availability Project (AWAP): CSIRO Marine and Atmospheric Research Component: Final Report for Phase 3, Canberra, 67 pp., 2009.

Reichstein, M., Falge, E., Baldocchi, D., Papale, D., Aubinet, M., Berbigier, P., Bernhofer, C., Buchmann, N., Gilmanov, T., Granier, A., Grünwald, T., Havránková, K., Ilvesniemi, H., Janous, D., Knohl, A., Laurila, T., Lohila, A., Loustau, D., Matteucci, G., Meyers, T., Miglietta, F., Ourcival, J. M., Pumpanen, J., Rambal, S., Rotenberg, E., Sanz, M., Tenhunen, J., Seufert, G., Vaccari, F., Vesala, T., Yakir, D., and Valentini, R.: On the separation of net ecosystem exchange into assimilation and ecosystem respiration: Review and improved algorithm, Glob. Change Biol., 11, 1424-1439, 2005.

Ryan, M. G.: Effects of climate change on plant respiration, Ecol. Appl., 1, 157-167, 1991.

Sankaran, M., Hanan, N. P., Scholes, R. J., Ratnam, J., Augustine, D. J., Cade, B. S., Gignoux, J., Higgins, S. I., Le Roux, X., and Ludwig, F.: Determinants of woody cover in African savannas, Nature, 438, 846-849, 2005.

Scheiter, S. and Higgins, S. I.: Impacts of climate change on the vegetation of Africa: an adaptive dynamic vegetation modelling approach, Glob. Change Biol., 15, 2224-2246, 2009.

Scholes, R. J. and Walker, B. H.: An African savanna: synthesis of the Nylsvley study, Cambridge University Press, 2004.

Schulze, E.-D., Williams, R., Farquhar, G., Schulze, W., Langridge, J., Miller, J., and Walker, B. H.: Carbon and nitrogen isotope discrimination and nitrogen nutrition of trees along a rainfall gradient in northern Australia, Funct. Plant Biol., 25, 413-425, 1998.

Schymanski, S. J., Sivapalan, M., Roderick, M. L., Hutley, L. B., and Beringer, J.: An optimality-based model of the dynamic feedbacks between natural vegetation and the water balance, Water Resources Research, 45, W01412, doi:10.1029/2008WR006841, 2009.

Sea, W. B. and Hanan, N. P.: Self-thinning and Tree Competition in Savannas, Biotropica, 44, 189-196, 2012. 
Sea, W. B., Choler, P., Beringer, J., Weinmann, R. A., Hutley, L. B., and Leuning, R.: Documenting improvement in leaf area index estimates from MODIS using hemispherical photos for Australian savannas, Agr. Forest Meteorol., 151, 1453-1461, 2011.

Shinozaki, K., Yoda, K., Hozumi, K., and Kira, T.: A Quantitative Analysis of Plant Form - The Pipe Model Theory I. Basic Analyses, Japanese J. Ecol., 14, 97-105, 1964.

Singh, K. P. and Misra, G.: Water-use efficiency of one C3 and two $\mathrm{C} 4$ grasses in response to varying soil moisture and herbageremoval levels in a seasonally dry tropical region, Plant Soil, 88, 171-180, 1985.

Sitch, S., Smith, B., Prentice, I. C., Arneth, A., Bondeau, A., Cramer, W., Kaplan, J., Levis, S., Lucht, W., and Sykes, M. T.: Evaluation of ecosystem dynamics, plant geography and terrestrial carbon cycling in the LPJ dynamic global vegetation model, Glob. Change Biol., 9, 161-185, 2003.

Sprugel, D. G., Ryan, M. G., Brooks, J., Vogt, K., and Martin, T. A.: Respiration from the organ level to the stand, Resource physiology of conifers, 1995, 255-299, 1995.

Swinbank, W. C.: Long-wave radiation from clear skies, Q. J. Roy. Meteorol. Soc., 89, 339-348, 1963.

Torello-Raventos, M., Feldpausch, T. R., Veenendaal, E., Schrodt, F., Saiz, G., Domingues, T. F., Djagbletey, G., Ford, A., Kemp, J., and Marimon, B. S.: On the delineation of tropical vegetation types with an emphasis on forest/savanna transitions, Plant Ecol. Divers., 6, 101-137, 2013.

Tucker, C. J., Pinzon, J. E., Brown, M. E., Slayback, D. A., Pak, E. W., Mahoney, R., Vermote, E. F., and El Saleous, N.: An extended AVHRR 8-km NDVI dataset compatible with MODIS and SPOT vegetation NDVI data, International J. Remote Sens., 26, 4485-4498, 2005.

Vogt, K., Vogt, D., Palmiotto, P., Boon, P., O’Hara, J., and Asbjornsen, H.: Review of root dynamics in forest ecosystems grouped by climate, climatic forest type and species, Plant Soil, 187, 159-219, 1995.
Von Caemmerer, S.: Biochemical models of leaf photosynthesis, Csiro publishing, 2000.

Wang, Y. P., Kowalczyk, E., Leuning, R., Abramowitz, G., Raupach, M. R., Pak, B., van Gorsel, E., and Luhar, A.: Diagnosing errors in a land surface model (CABLE) in the time and frequency domains, J. Geophys. Res.-Biogeo., 116, G01034, doi:10.1029/2010JG001385, 2011.

Ward, D., Wiegand, K., and Getzin, S.: Walter's two-layer hypothesis revisited: back to the roots!, Oecologia, 172, 617-630, 2013.

Whitley, R. J., Macinnis-Ng, C. M. O., Hutley, L. B., Beringer, J., Zeppel, M., Williams, M., Taylor, D., and Eamus, D.: Is productivity of mesic savannas light limited or water limited? Results of a simulation study, Glob. Change Biol., 17, 3130-3149, 2011.

Williams, R., Gill, A., and Moore, P.: Seasonal Changes in Fire Behaviour in a Tropical Savanna in Northern Australia, Int. J. Wildland Fire, 8, 227-239, 1998.

Williams, R. J., Duff, G. A., Bowman, D., and Cook, G. D.: Variation in the composition and structure of tropical savannas as a function of rainfall and soil texture along a large-scale climatic gradient in the Northern Territory, Australia, J. Biogeogr., 23, 747-756, 1996.

Wright, I. J., Westoby, M., and Reich, P. B.: Convergence towards higher leaf mass per area in dry and nutrient-poor habitats has different consequences for leaf life span, J. Ecol., 90, 534-543, 2002.

Zhu, Z., Bi, J., Pan, Y., Ganguly, S., Anav, A., Xu, L., Samanta, A., Piao, S., Nemani, R. R., and Myneni, R. B.: Global data sets of vegetation leaf area index (LAI) $3 g$ and Fraction of Photosynthetically Active Radiation (FPAR) 3g derived from Global Inventory Modeling and Mapping Studies (GIMMS) Normalized Difference Vegetation Index (NDVI3g) for the period 1981 to 2011, Remote Sens., 5, 927-948, 2013. 